\title{
Environmental forcing does not induce diel or synoptic variation in the carbon isotope content of forest soil respiration
}

\author{
D. R. Bowling ${ }^{1}$, J. E. Egan ${ }^{2}$, S. J. Hall ${ }^{3}$, and D. A. Risk ${ }^{4}$ \\ ${ }^{1}$ Department of Biology, University of Utah, Salt Lake City, Utah, USA \\ ${ }^{2}$ Department of Earth Sciences, Dalhousie University, Halifax, Nova Scotia, Canada \\ ${ }^{3}$ Global Change and Sustainability Center, Univ. of Utah, Salt Lake City, Utah, USA \\ ${ }^{4}$ Department of Earth Sciences, St. Francis Xavier University, Antigonish, Nova Scotia, Canada \\ Correspondence to: D. R. Bowling (david.bowling@utah.edu)
}

Received: 1 April 2015 - Published in Biogeosciences Discuss.: 29 April 2015

Revised: 7 August 2015 - Accepted: 14 August 2015 - Published: 31 August 2015

\begin{abstract}
Recent studies have examined temporal fluctuations in the amount and carbon isotope content $\left(\delta^{13} \mathrm{C}\right)$ of $\mathrm{CO}_{2}$ produced by the respiration of roots and soil organisms. These changes have been correlated with diel cycles of environmental forcing (e.g., sunlight and soil temperature) and with synoptic-scale atmospheric motion (e.g., rain events and pressure-induced ventilation). We used an extensive suite of measurements to examine soil respiration over 2 months in a subalpine forest in Colorado, USA (the Niwot Ridge AmeriFlux forest). Observations included automated measurements of $\mathrm{CO}_{2}$ and $\delta^{13} \mathrm{C}$ of $\mathrm{CO}_{2}$ in the soil efflux, the soil gas profile, and forest air. There was strong diel variability in soil efflux but no diel change in the $\delta^{13} \mathrm{C}$ of the soil efflux $\left(\delta_{\mathrm{R}}\right)$ or the $\mathrm{CO}_{2}$ produced by biological activity in the soil $\left(\delta_{\mathrm{J}}\right)$. Following rain, soil efflux increased significantly, but $\delta_{\mathrm{R}}$ and $\delta_{\mathrm{J}}$ did not change. Temporal variation in the $\delta^{13} \mathrm{C}$ of the soil efflux was unrelated to measured environmental variables, and we failed to find an explanation for this unexpected result. Measurements of the $\delta^{13} \mathrm{C}$ of the soil efflux with chambers agreed closely with independent observations of the isotopic composition of soil $\mathrm{CO}_{2}$ production derived from soil gas well measurements. Deeper in the soil profile and at the soil surface, results confirmed established theory regarding diffusive soil gas transport and isotopic fractionation. Deviation from best-fit diffusion model results at the shallower depths illuminated a pump-induced ventilation artifact that should be anticipated and avoided in future studies. There was no evidence of natural pressureinduced ventilation of the deep soil. However, higher variability in $\delta^{13} \mathrm{C}$ of the soil efflux relative to $\delta^{13} \mathrm{C}$ of production
\end{abstract}

derived from soil profile measurements was likely caused by transient pressure-induced transport with small horizontal length scales.

\section{Introduction}

The efflux of $\mathrm{CO}_{2}$ from soils results from the collective contribution of a host of physiologically diverse organisms. Processes influencing soil respiration are complex and vary based on a variety of biological, biophysical, and biogeochemical factors. World soils are a major storage reservoir for carbon, and soil respiration represents the largest gross transfer of carbon to the atmosphere, much larger than anthropogenic sources (Le Quéré et al., 2013; Raich and Schlesinger, 1992). Understanding the complicated role of the biosphere in the global carbon cycle is thus essential for the prediction of future climate (Friedlingstein et al., 2014; Heimann and Reichstein, 2008).

Respiration by soils is dependent on temperature and moisture (Davidson et al., 1998; Lloyd and Taylor, 1994), the composition of the community of soil organisms (Bardgett et al., 2008), and the quality of organic compounds used to fuel heterotrophic metabolism (Conant et al., 2011). In addition, there is strong evidence that soil respiration is linked to plant photosynthesis (Kuzyakov and Gavrichkova, 2010). Because of this linkage, a large fraction of carbon in the soil efflux has resided in the biosphere for only hours, days or weeks (Högberg et al., 2001). 
The connection between photosynthesis and soil respiration has led many to examine the stable carbon isotopic composition $\left(\delta^{13} \mathrm{C}\right)$ of respiration in the context of environmental controls on photosynthesis such as sunlight, soil moisture, and humidity (Bowling et al., 2008). For example, changes in soil moisture and humidity influence stomatal conductance of $C_{3}$ plants, altering photosynthetic discrimination, leading via root respiration or exudation to changes in $\delta^{13} \mathrm{C}$ of soil efflux and whole-forest respiration (Ekblad and Högberg, 2001; Lai et al., 2005). Others have used $\delta^{13} \mathrm{C}$ of soil efflux to assess the relative contributions of autotrophic and heterotrophic respiration (Kuzyakov, 2006) or added isotopic labels via organic material (Bird and Torn, 2006) or via photosynthesis (Högberg et al., 2008) to investigate soil carbon cycle processes. Several studies have identified diel variation in the $\delta^{13} \mathrm{C}$ of plant and soil respiration (reviewed by Werner and Gessler, 2011), and others have highlighted changes in rate and $\delta^{13} \mathrm{C}$ of soil efflux following rain (e.g., Jarvis et al., 2007; Unger et al., 2012). Presumably such changes involve the varied consumption of organic substrates for heterotrophic activity that differ systematically in $\delta^{13} \mathrm{C}$, such as starch, lignin, or cellulose (Bowling et al., 2008). However, there are a wide variety of post-photosynthetic fractionation processes that influence the $\delta^{13} \mathrm{C}$ of respiration and of $\mathrm{CO}_{2}$ in the soil, many of which are poorly understood (Brüggemann et al., 2011; Ghashghaie and Badeck, 2014).

Many ecologists use soil efflux as a measure of the simultaneous rate of production within the soil. (In this paper we use "soil efflux" to refer to the rate of transport of $\mathrm{CO}_{2}$ from the soil surface to the atmosphere, "soil $\mathrm{CO}_{2}$ " to refer to the mole fraction of $\mathrm{CO}_{2}$ in the soil pore space with respect to dry air, and "production" to refer to the process rate of biological production of $\mathrm{CO}_{2}$ by soil organisms and roots.) However, soil efflux and production are not always tightly coupled. Permeable soils are subject to ventilation by wind or pressure changes (e.g., Flechard et al., 2007), with sometimes dramatic changes in soil $\mathrm{CO}_{2}$ over just a few hours or days (Sánchez-Cañete et al., 2013). Sometimes ventilation is less obvious, but a comparison of measurements of soil efflux and soil $\mathrm{CO}_{2}$ with models of diffusive transport suggests that ventilation may be persistent in some soils (Roland et al., 2015). Because aerobic respiration involves $\mathrm{CO}_{2}$ production that is stoichiometrically related to $\mathrm{O}_{2}$ consumption, the ratio of these two fluxes (apparent respiratory quotient or ARQ) can be used to identify the presence of other processes in the soil that can lead to decoupling between $\mathrm{CO}_{2}$ efflux and production. The ARQ method has highlighted the importance of $\mathrm{CO}_{2}$ dissolution in soil water, carbonate dissolution and precipitation, and possibly the oxidation of reduced iron (Angert et al., 2015). Finally, $\mathrm{CO}_{2}$ transported through the xylem can be similar in magnitude to soil efflux (Aubrey and Teskey, 2009). All of these factors would lead to differences in the rates of production within the soil and soil efflux.

Due to fractionation associated with diffusion, stable isotopes of $\mathrm{CO}_{2}$ provide a useful means to examine soil gas
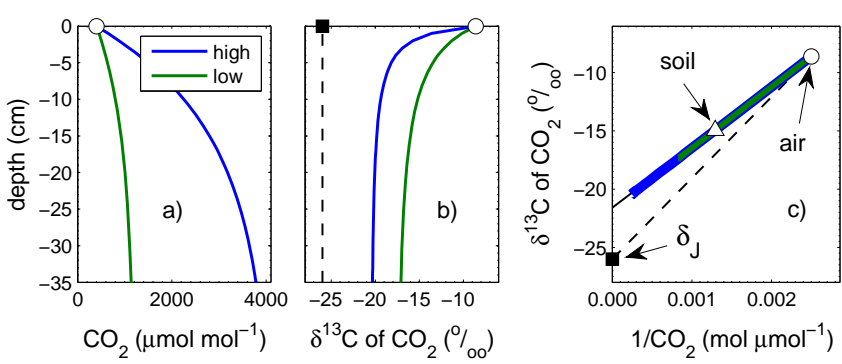

Figure 1. Modeled steady-state diffusive vertical profiles of (a) soil pore space $\mathrm{CO}_{2}$, (b) $\delta^{13} \mathrm{C}$ of soil pore space $\mathrm{CO}_{2}$, and (c) the relationship between them, shown for low and high flux rates (colors). The $\mathrm{CO}_{2}$ and $\delta^{13} \mathrm{C}$ of $\mathrm{CO}_{2}$ in forest air at the soil-air boundary $\left(C_{\mathrm{a}}\right.$, $\delta_{\mathrm{a}}$ ) are shown (circle) along with the $\delta^{13} \mathrm{C}$ of the $\mathrm{CO}_{2}$ produced by respiration $\left(\delta_{\mathrm{J}}\right.$, square and vertical dashed line in $\left.(\mathbf{b})\right)$. The colored lines in (a) and (b) both fall on the upper (diffusive) solid line in (c). The triangle in (c) denotes an individual gas well measurement of soil pore space $\left(C_{\mathrm{S}}, \delta_{\mathrm{S}}\right)$, which when combined with measurements of forest air allows calculation of $\delta \mathrm{J}$ via Eq. (1). Symbols are labeled in panel (c) and are the same in all panels.

transport processes. There is a well-established physical understanding of the transport of $\mathrm{CO}_{2}$ and its stable isotope variants within soils (Amundson et al., 1998; Cerling, 1984; Cerling et al., 1991). Carbon dioxide within the soil pore space reflects the dynamic mixing of biological production (which varies in time and space) with atmospheric $\mathrm{CO}_{2}$ under the influence of diffusion. Modeled diffusive profiles of soil $\mathrm{CO}_{2}$ (which we denote $C_{\mathrm{S}}$ ) and $\delta^{13} \mathrm{C}$ of $\mathrm{CO}_{2}$ in the soil $\left(\delta_{\mathrm{S}}\right)$ are shown in Fig. 1. (See Table 1 for a complete list of symbols; model details are provided in Sect. 2.7.) The presence of air at the soil surface forces a boundary condition so that $C_{\mathrm{S}}$ and $\delta_{\mathrm{S}}$ must match the $\mathrm{CO}_{2}$ and isotope ratio of forest air $\left(C_{\mathrm{a}}\right.$ and $\delta_{\mathrm{a}}$; circles). Within the soil, $\mathrm{CO}_{2}$ increases with depth, with higher $\mathrm{CO}_{2}$ in the soil pore space under conditions of higher biological production (Fig. 1a; the colored lines differ only in the rates of production). There is a corresponding decrease in $\delta_{\mathrm{S}}$ with depth, and it is more negative with higher production (Fig. 1b). The isotopic composition of production in these simulations was fixed at $-26 \%$ in both high- and low-production scenarios (squares in Fig. 1b, c).

Due to the difference in mass of ${ }^{12} \mathrm{CO}_{2}$ and ${ }^{13} \mathrm{CO}_{2}$, transport by molecular diffusion of $\mathrm{CO}_{2}$ in air leads to a $4.4 \%$ o fractionation (Cerling et al., 1991). Hence $\delta_{\mathrm{S}}$ in the bulk gas within the soil profile is never equal to the signature of production $(-26 \%$ ); instead, it is always enriched (less negative; compare dashed line to colored lines in Fig. 1b). Note, however, that due to mixing with atmospheric $\mathrm{CO}_{2}$, the difference between the signature of production (dashed line) and $\delta_{\mathrm{S}}$ can be much greater than $4.4 \%$, especially near the surface and when the rate of production is low.

The mixing of $\mathrm{CO}_{2}$ from biological production (square) with forest air (circle) is illustrated in Fig. 1c. If there were no 
Table 1. List of symbols used.

\begin{tabular}{|c|c|c|}
\hline Symbol & Description & Unit \\
\hline$C$ & $\mathrm{CO}_{2}$ mole fraction relative to dry air & $\mu \mathrm{mol} \mathrm{mol}{ }^{-1}$ \\
\hline$C_{\mathrm{a}}$ & $\mathrm{CO}_{2}$ in air above the soil & $\mu \mathrm{mol} \mathrm{mol}-1$ \\
\hline$C_{\mathrm{S}}$ & $\mathrm{CO}_{2}$ in soil pore space & $\mu \mathrm{mol} \mathrm{mol}-1$ \\
\hline$D$ & soil gas diffusivity & $\mathrm{m}^{2} \mathrm{~s}^{-1}$ \\
\hline$\delta^{13} \mathrm{C}$ & stable $\left({ }^{13} \mathrm{C} /{ }^{12} \mathrm{C}\right)$ isotope composition (relative to VPDB) & $\%$ \\
\hline$\delta_{\mathrm{a}}$ & $\delta^{13} \mathrm{C}$ of $\mathrm{CO}_{2}$ in air above the soil & $\% o$ \\
\hline$\delta_{\mathrm{F}}$ & $\delta^{13} \mathrm{C}$ of whole-forest respiration & $\%$ \\
\hline$\delta_{\mathrm{J}}$ & $\delta^{13} \mathrm{C}$ of soil $\mathrm{CO}_{2}$ production, calculated using Eq. (1) & $\%$ \\
\hline$\delta_{\mathrm{R}}$ & $\delta^{13} \mathrm{C}$ of soil surface $\mathrm{CO}_{2}$ flux & $\%$ \\
\hline$\delta_{\mathrm{S}}$ & $\delta^{13} \mathrm{C}$ of soil pore space $\mathrm{CO}_{2}$ & $\%$ \\
\hline$\varepsilon$ & model fit error metric & dimensionless \\
\hline$\eta$ & $e$-folding depth of soil production function & $\mathrm{m}$ \\
\hline $\mathrm{L}$ & lower model depth boundary & $\mathrm{m}$ \\
\hline$\lambda$ & arbitrary parameter to constrain production to 0 to $\mathrm{L}$ & $\mathrm{m}$ \\
\hline$P(z, t)$ & biological production at depth $z$ and time $t$ & $\mathrm{~mol} \mathrm{CO}_{2} \mathrm{~m}^{-3} \mathrm{~s}^{-1}$ \\
\hline$P_{\mathrm{O}}$ & total biological production integrated over full soil & $\mathrm{mol} \mathrm{CO} \mathrm{m}^{-2} \mathrm{~s}^{-1}$ \\
\hline$\rho_{\mathrm{a}}$ & molar density of air & mol air $\mathrm{m}^{-3}$ \\
\hline$t$ & time & $\mathrm{s}$ \\
\hline$\theta$ & air-filled porosity of soil & dimensionless \\
\hline$X$ & $\mathrm{CO}_{2}$ concentration in soil & $\mathrm{mol} \mathrm{CO}_{2} \mathrm{~m}^{-3}$ \\
\hline$z$ & depth & $\mathrm{m}$ \\
\hline
\end{tabular}

diffusion, mixing of these two sources would follow a linear combination reflecting the proportion of each (dashed line, Keeling, 1958). Instead, mixing by diffusion follows the upper line, and the $\delta^{13} \mathrm{C}$ vs. $1 / \mathrm{CO}_{2}$ relation is identical in both the high- and low-production cases. The $y$ intercepts of the upper and lower lines differ by $4.4 \%$. Under fully diffusive conditions, the isotopic composition of biological production (square; $\delta_{\mathrm{J}}$ ) can be calculated from a pair of measurements of $\mathrm{CO}_{2}$ in air (circle; $C_{\mathrm{a}}, \delta_{\mathrm{a}}$ ) and in the soil pore space (triangle; $C_{\mathrm{S}}, \delta_{\mathrm{S}}$ ) using this equation (derived by Davidson, 1995):

$\delta_{\mathrm{J}}=\frac{C_{\mathrm{S}}\left(\delta_{\mathrm{S}}-4.4\right)-C_{\mathrm{a}}\left(\delta_{\mathrm{a}}-4.4\right)}{1.0044\left(C_{\mathrm{S}}-C_{\mathrm{a}}\right)}$

Mixing of soil-respired $\mathrm{CO}_{2}$ with air under conditions that involve even a minor amount of advection, such as with windy conditions within a snowpack, will lead to $C_{\mathrm{S}}$ and $\delta_{\mathrm{S}}$ that fall between the two lines in Fig. 1c (Bowling et al., 2009; Bowling and Massman, 2011). We anticipate that this pattern would be observed in any porous medium (such as soil) where diffusion dominates transport that is exposed to ventilation by pressure or wind forcing, even if very low bulk fluid flow is involved. Further, the vertical profiles of $C_{\mathrm{S}}$ and $\delta_{\mathrm{S}}$ in soils during ventilation should deviate from fully diffusive profiles such as those in Fig. 1a, b.

Given the complexities of the many biological and physical processes influencing the isotopic content of $\mathrm{CO}_{2}$ in the soil-atmosphere exchange and the wide variety of ways that isotopes of $\mathrm{CO}_{2}$ have been used to interpret these processes, we were motivated to conduct an extensive observa- tional study. We used three independent measurement methods combined with soil gas transport modeling to continuously examine $\mathrm{CO}_{2}$ in the soil pore space, forest air, and soil efflux in a high-elevation subalpine forest to test the following hypotheses:

1. The $\delta^{13} \mathrm{C}$ of soil efflux changes on a daily (diel) basis.

2. Rain following a dry period leads to changes in $\delta^{13} \mathrm{C}$ of soil efflux as the activity of the soil heterotrophic community is altered.

3. Barometric pressure changes associated with the passage of weather systems leads to the ventilation of the soil gas profile.

\section{Methods}

\subsection{Study location}

This study was conducted at the Niwot Ridge AmeriFlux forest (http://ameriflux.lbl.gov) in the Rocky Mountains of Colorado, United States $\left(40.03^{\circ} \mathrm{N}, 105.55^{\circ} \mathrm{W} ; 3050 \mathrm{~m}\right.$ elevation). The subalpine forest is dominated by the conifer species Pinus contorta, Picea engelmannii, and Abies lasiocarpa, with sparse understory cover of Vaccinium species, lichens, and mosses. The forest is on a late-Pleistocene glacial moraine with generally thin (mean $60 \mathrm{~cm}$ ) sandy and/or rocky Inceptisols covered by a thin $(<10 \mathrm{~cm})$ organic horizon (Cole and Braddock, 2009; Lewis Jr. and Grant, 


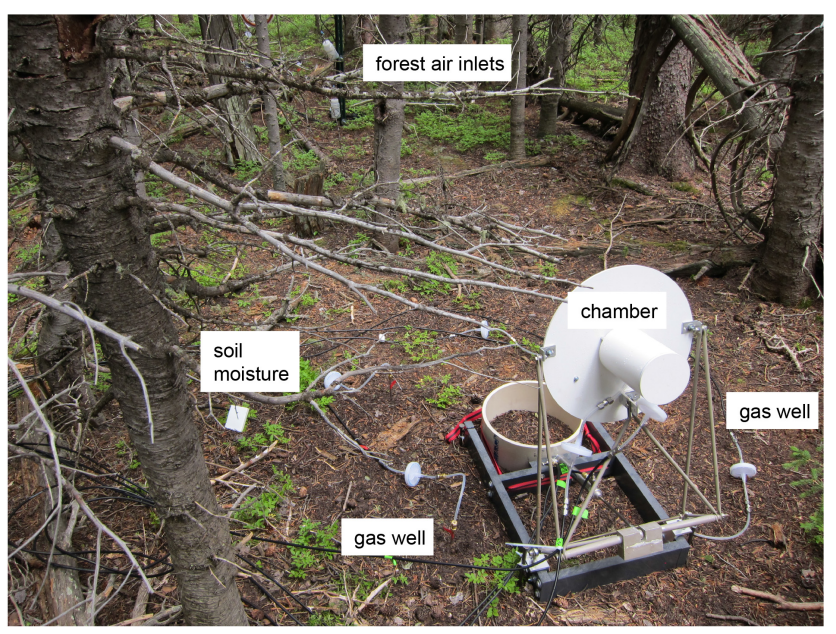

Figure 2. Instrumentation installed at the Niwot Ridge forest for this study, including an automated soil surface flux chamber, the gas wells surrounding it (steel tubing inserted vertically into the ground with white filters connected to black tubing), and the top of a soil moisture probe. Inlets for forest air measurement can be seen at the top, attached to a fencepost.

1979; Scott-Denton et al., 2003; Xiong et al., 2011). The site includes a highly instrumented tower from which the biosphere-atmosphere exchange of $\mathrm{CO}_{2}$ has been monitored since 1998 (Monson et al., 2002). Barometric pressure and wind data were obtained from the AmeriFlux data archive (http://ameriflux.lbl.gov/) for this study.

\subsection{Experimental design}

Field observations were conducted during AugustSeptember 2011 (65 days total) in an undisturbed area within $30 \mathrm{~m}$ of the flux tower (see image in Fig. 2). Three soil locations were selected at random within $5 \mathrm{~m}$ of a short mast where continuous measurements of forest air $\mathrm{CO}_{2}$ and its isotopes have been made for over 9 years (Bowling et al., 2014). At each location, an automated soil chamber was installed to monitor soil efflux, and adjacent to each chamber, soil temperature (107 thermistor probe, Campbell Scientific, Inc., Logan, UT, USA) was measured at the interface of the organic and mineral horizons (O/A interface). Soil moisture was monitored in the $\mathrm{O}$ horizon and the top $10 \mathrm{~cm}$ of the $\mathrm{A}$ horizon with a single depth-integrating sensor (CS615 water content reflectometer, Campbell Scientific, Inc., Logan, UT, USA). Gas wells were installed at four depths surrounding each chamber to monitor soil pore gas. The chambers and gas wells were connected to a central analyzer to measure soil gas composition (see next sections).

\section{3 $\mathrm{CO}_{2}$ and its isotopes}

The carbon dioxide mole fraction and carbon isotope ratio in chamber, soil pore space, and forest air were measured using tunable diode laser absorption spectroscopy (TDLAS, TGA100A, Campbell Scientific, Inc., Logan, UT, USA). The TDLAS instrument and calibration procedure have been described elsewhere (Bowling et al., 2009; Schaeffer et al., 2008). Observations are presented relative to the World Meteorological Organization $\mathrm{CO}_{2}$ mole fraction scale (WMO $\mathrm{X} 2007$ ) and the International Atomic Energy Agency Vienna Pee Dee Belemnite (VPDB) scale, respectively. High $\mathrm{CO}_{2}$ mole fractions in the soil were diluted with $\mathrm{CO}_{2}$-free air using mass flow controllers into the measurable range for the analyzer (Bowling et al., 2009). Measured flow rates were used to calculate mole fractions of the original soil gas, which usually exceeded the defined range of the WMO X2007 scale (maximally $521 \mu \mathrm{mol} \mathrm{mol}^{-1}$ ).

\subsection{Automated soil chambers and $\delta_{R}$}

Small $(<1 \mathrm{~Pa})$ chamber-air pressure gradients have been shown to erroneously and markedly influence soil $\mathrm{CO}_{2}$ efflux (Fang and Moncrieff, 1998). Given the diffusive fractionation for $\mathrm{CO}_{2}$ isotopes, for our application it was critical to use chambers that would minimally disturb the soil diffusive environment. Steady-state dynamic chambers were used following the design of Rayment and Jarvis (1997) to minimize differential pressure between the chamber and the soil (Fig. 2). Laboratory tests with the chambers sealed to a solid impermeable bench top (Xu et al., 2006) indicated that chamber-air differential pressure was less than $0.2 \mathrm{~Pa}$ at flow rates below and including $4 \mathrm{~L} \mathrm{~min}^{-1}$ (data not shown), so $4 \mathrm{~L} \mathrm{~min}^{-1}$ was used in the field. Closure of chambers was automated using pneumatic pistons following the design of Riggs et al. (2009).

One chamber was measured each hour, with each chamber measured at staggered $3 \mathrm{~h}$ intervals (eight measurements per chamber per day). During a measurement, chamber lids were closed for $20 \mathrm{~min} . \mathrm{CO}_{2}$ in the inlet and outlet were monitored for alternating $1 \mathrm{~min}$ periods while the chamber was closed using an infrared gas analyzer (LI-820, LI-COR, Lincoln, NE, USA). During closure, $\mathrm{CO}_{2}$ in the outlet increased slowly and then stabilized as a new steady state was reached. TDLAS measurements were made during the last $6 \mathrm{~min}$ of the closure period, with alternate measurement of the inlet and outlet of the chamber continuing to be alternated for 1 min each (but always with a constant flow through the chamber). The $\mathrm{CO}_{2}$ mole fraction difference between inlet and outlet during the last 6 min was stable and averaged $81 \pm 21 \mu \mathrm{mol} \mathrm{mol}^{-1}$ (mean and standard deviation, $n=1284$ chamber measurements). The soil $\mathrm{CO}_{2}$ efflux and $\delta^{13} \mathrm{C}$ of soil efflux (which we will refer to as $\delta_{R}$ ) were calculated from the $\mathrm{CO}_{2}$ and $\delta^{13} \mathrm{C}$ measurements of the inlet and outlet gas streams using equations provided by Moyes et al. (2010). 


\subsection{Gas wells and $\delta_{\mathrm{J}}$}

Gas wells were used to monitor soil pore gas with as little disturbance as possible - no digging was required except for the shallowest gas well that required minor digging. Wells were installed at four depths within $1 \mathrm{~m}$ horizontally of each chamber (12 wells in total); these were at the O/A interface and 5, 10 , and $30 \mathrm{~cm}$ below the top of the mineral soil. The O/A interface wells consisted of stainless steel cylinders of $10 \mathrm{~cm}$ diameter and $1 \mathrm{~cm}$ tall with steel mesh on the top and bottom (Sommerfeld et al., 1991), inserted by hand. Remaining wells were made of $6 \mathrm{~mm}$ OD stainless steel tubing, inserted vertically into the soil surface with a hammer. A metal rod was used during insertion to prevent clogging the tube with soil or roots, and then the rod was removed. All gas wells were attached to a $1.0 \mu \mathrm{m}$ PTFE filter (Acro-50, Pall Corporation, East Hills, NY, USA) and connected to the TDLAS sampling manifold with variable lengths (tens of meters) of $6 \mathrm{~mm}$ OD tubing (Type 1300, Synflex Specialty Products, Mantua, $\mathrm{OH}$, USA). The volume of each length of tubing was measured after field installation using a pressure change when adding evacuated tubing to a known volume using the ideal gas law. This allowed soil gas to be pumped to the analyzer at a controlled flow rate with a known arrival time. This was tested repeatedly in the field by introducing a step change in $\mathrm{CO}_{2}$ in each length of tubing and watching for its arrival at the analyzer. Sampling flow rate was $235 \mathrm{~mL} \mathrm{~min}^{-1}$, and gas flowed in each inlet for 10 min during measurement. The $10 \mathrm{~s}$ period immediately following the arrival of the gas at the end of the tubing was averaged for each measurement. Thus the perturbation in the soil gas well involved a total volume of $2.35 \mathrm{~L}$, and $3 \mathrm{~h}$ elapsed before the next measurement of a given well. The four gas wells surrounding a chamber were measured over a $20 \mathrm{~min}$ period, and this was repeated every $3 \mathrm{~h}$ (offsetting the three chamber locations each hour), providing eight measurements per day for each well. The wells surrounding each chamber were measured $3 \mathrm{~h}$ after the chamber was measured to avoid disrupting each type of observation with the other. In total 4350 gas well measurements were made (69\% coverage due to occasional clogging with water or power loss).

The isotopic composition of belowground $\mathrm{CO}_{2}$ production $\left(\delta_{\mathrm{J}}\right)$ was calculated for all individual gas well measurement pairs $\left(C_{\mathrm{S}}, \delta_{\mathrm{S}}\right)$ using Eq. (1). The forest air inlet to the soil surface chamber nearest the well was used for $C_{\mathrm{a}}$ and $\delta_{\mathrm{a}}$ and interpolated to match the gas well measurement in time using a piecewise Hermite interpolation (Matlab R2013a, The Mathworks, Natick, MA, USA).

\subsection{Carbon isotope content of whole-forest respiration} $\left(\delta_{F}\right)$

The $\delta^{13} \mathrm{C}$ of whole-forest respiration $\left(\delta_{\mathrm{F}}\right)$ was calculated for the entire study period from mixing lines (Ballantyne et al., 2011) between $\mathrm{CO}_{2}$ and $\delta^{13} \mathrm{C}$ of $\mathrm{CO}_{2}$ in forest air at nine heights, using nighttime data only. This involved the removal of synoptic changes in the composition of air by subtracting the observation at the top of the tower; details can be found in Bowling et al. (2014).

\subsection{Soil diffusive gas transport model}

To test the hypothesis that barometric pressure change leads to ventilation of the soil pore space, we compared soil pore space observations $\left(C_{\mathrm{S}}, \delta_{\mathrm{S}}\right)$ to model simulations produced using a steady-state soil gas transport model (Cerling, 1984; Nickerson et al., 2014). The model was based on Fick's second law of diffusion:

$\theta \frac{\partial X}{\partial t}=\frac{\partial}{\partial z}\left(D(z, t) \frac{\partial X}{\partial z}\right)+P(z t)$,

where $\theta$ is the air-filled porosity of the soil, $X$ is the gas concentration, $D(z, t)$ is the soil gas diffusivity and $P(z, t)$ represents biological production as a function of depth $(z)$ and time $(t)$. We assumed steady-state conditions $(\mathrm{d} X / \mathrm{d} t=0)$, soil gas diffusivity was constant with depth $(D(z)=D)$, and biological production decreased exponentially with depth as

$P(z)=\frac{P_{\mathrm{o}}}{\lambda} e^{-z / \eta}$,

where $P_{\mathrm{o}}$ is the total soil efflux (production integrated over the entire soil depth), $\eta$ is the depth at which production is reduced to $1 / e$ of its value at $z=0$ ( $e$-folding depth), and $\lambda$ is a parameter which constrains production to occur within the soil depths 0 to $L$, where $L$ is the lower $(z)$ model boundary, with no $\mathrm{CO}_{2}$ production or diffusion occurring below it. The upper soil surface must interact with the air in the forest providing an upper model boundary condition,

$X(z=0)=\rho_{\mathrm{a}} C_{\mathrm{a}}$,

and an assumption of a no-flux lower boundary provided a second:

$\left.\frac{\partial X}{\partial z}\right|_{z=L}=0$.

Similar steady-state equations were used for ${ }^{12} \mathrm{CO}_{2}$ and ${ }^{13} \mathrm{CO}_{2}$, treating each isotopologue of $\mathrm{CO}_{2}$ as an independent gas with its own diffusivity and biological production rate (Cerling et al., 1991). For a full derivation of both steadystate equations, see Nickerson et al. (2014).

The above equations were solved numerically (Mathematica NDSolve version 9.0.1; Wolfram Research, Champaign, IL, USA) using a broad range of values for each parameter, with coarse steps. Model best fits were determined (see below) and model parameter optimization was performed, where the optimized model produced $\sim 600$ synthetic solutions with the following parameters: soil gas diffusivity $(D$; $5 \times 10^{-6}$ to $8 \times 10^{-6} \mathrm{~m}^{2} \mathrm{~s}^{-1}$ in steps of 0.5$), e$-folding depth 


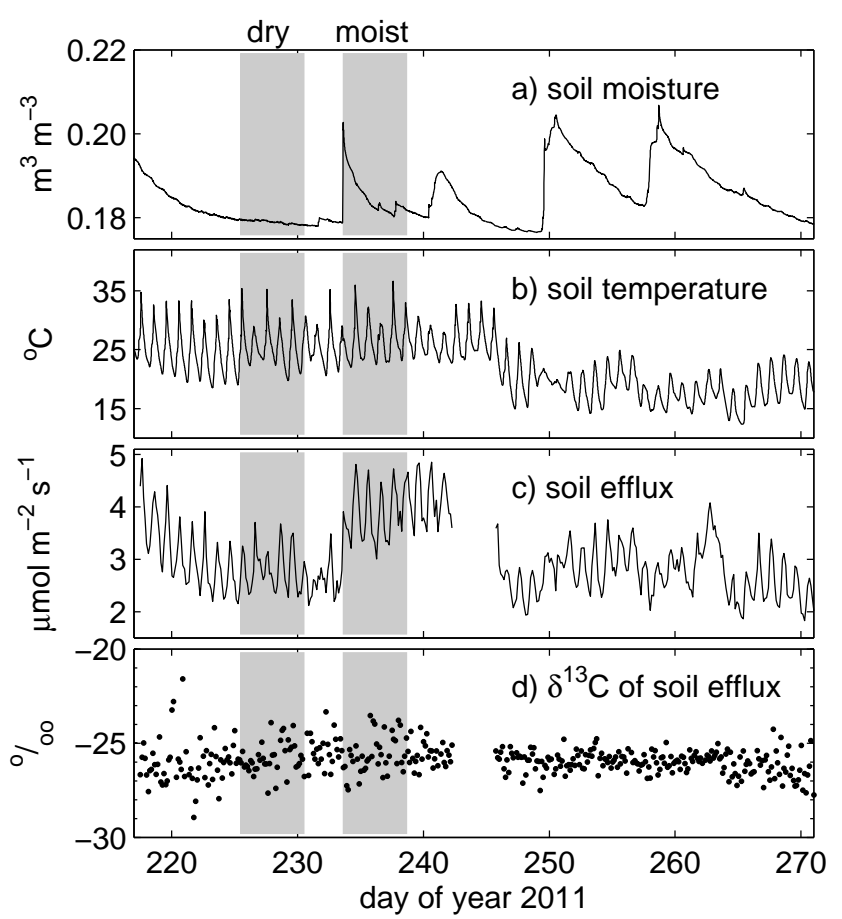

Figure 3. Soil moisture $(0-10 \mathrm{~cm})$, soil temperature $(5 \mathrm{~cm})$, soil efflux, and $\delta^{13} \mathrm{C}$ of soil efflux $\left(\delta_{\mathrm{R}}\right)$ measured at the location of chamber 1 over the duration of the experiment. Five-day dry and moist time periods are highlighted with shading.

$(\eta ; 0.01$ to $0.60 \mathrm{~m}$ in steps of 0.1 ), and model lower boundary depth $(L ; 0.3$ to $2 \mathrm{~m}$ in steps of 0.1$)$. Mean values for the rate of production $\left(P_{\mathrm{o}}\right), \delta^{13} \mathrm{C}$ of production, $\mathrm{CO}_{2}$ mole fraction and $\delta^{13} \mathrm{C}$ of $\mathrm{CO}_{2}$ in forest air were determined from measurements (soil efflux, $\delta_{\mathrm{R}}, C_{\mathrm{a}}, \delta_{\mathrm{a}}$, respectively) for the time periods of interest (described in the "Results" section) and used as forcing input.

Model results consisted of a family of gas profiles for the range of parameters examined and were entirely independent of the soil pore space observations. Model output consisted of ${ }^{12} \mathrm{CO}_{2}$ and ${ }^{13} \mathrm{CO}_{2}$ concentration profiles (in $1 \mathrm{~cm}$ increments) that were converted to $\mathrm{CO}_{2}$ and $\delta^{13} \mathrm{C}$ profiles. These were compared to measured gas profiles in the soil (mean values for $C_{\mathrm{S}}$ and $\delta_{\mathrm{S}}$ over the period of interest) by calculating the root mean square (RMS) difference between the model output and the measured values at the depths of measurement. A best-fit diffusion model result was selected by optimizing for both $\mathrm{CO}_{2}$ and $\delta^{13} \mathrm{C}$ by minimizing the dimensionless error metric

$\varepsilon=\left(\frac{\operatorname{RMS}\left(C_{\mathrm{S}}\right)}{\operatorname{range}\left(C_{\mathrm{S}}\right)}\right)\left(\frac{\operatorname{RMS}\left(\delta_{\mathrm{S}}\right)}{\operatorname{range}\left(\delta_{\mathrm{S}}\right)}\right)$,

where each individual root-mean-square (RMS) error (for $C_{\mathrm{S}}$ or $\delta_{\mathrm{S}}$ ) was normalized by the range of values observed for that time period.

The model-data comparison was conducted (1) using observations from all gas well measurement depths and (2)

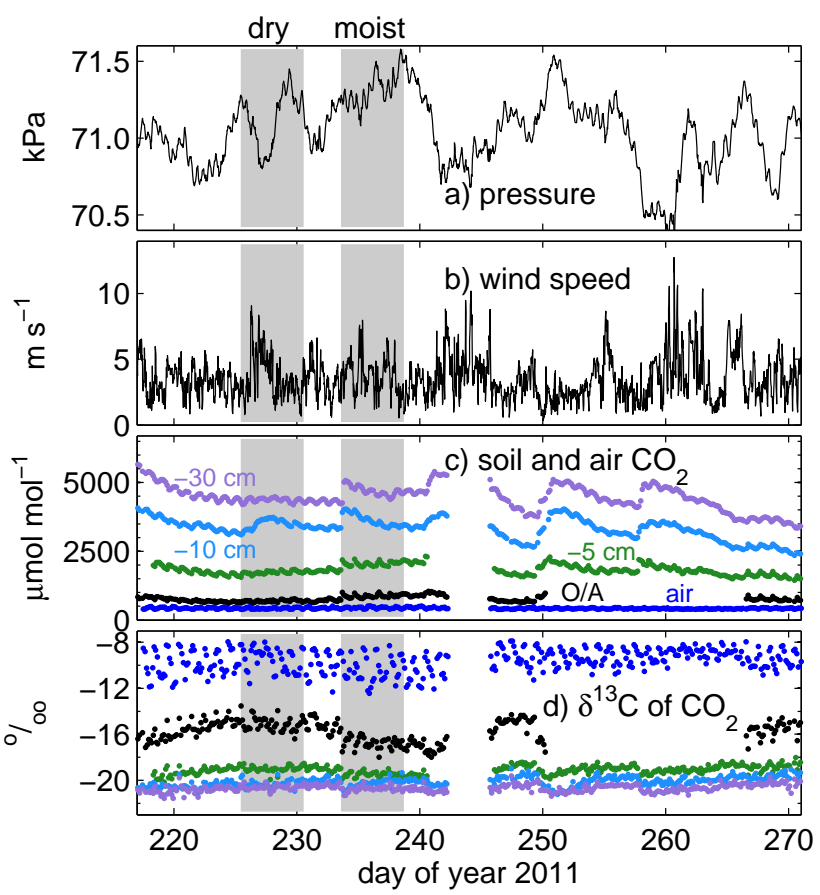

Figure 4. Barometric pressure (12 m), wind speed (21 $\mathrm{m}), \mathrm{CO}_{2}$ and $\delta^{13} \mathrm{C}$ of $\mathrm{CO}_{2}$ in soil pore space and forest air measured at the location of chamber 1 over the duration of the experiment, with dry and moist time periods shaded. Depths of soil gas for (c) and (d) were at the O/A horizon interface, $-5,-10$ and $-30 \mathrm{~cm}$ (colors indicated in $\mathbf{c})$.

using only the lowest three depths (omitting measurements from the O/A interface). The latter was done after identifying a measurement artifact that will be described below.

\section{Results}

Time series of soil moisture and temperature are shown with efflux data from chamber 1 in Fig. 3 (data from the other chambers were similar). Soil temperature varied by as much as $10^{\circ} \mathrm{C}$ on a diel basis and led to significant diel variability in soil efflux (Table 2; Fig. 3). Soil efflux was systematically higher in chamber 3 compared to the others, although soil temperature was similar (Table 2). There were several rain events during the study; 5-day periods with dry soil and after the first large rain event were selected for closer analysis ("dry" and "moist" periods, shaded in Fig. 3). The first major rain event increased soil efflux by 26-39\% during the moist period relative to the dry period, but there was no concurrent change in soil temperature (Table 2; Fig. 3). The $\delta^{13} \mathrm{C}$ of soil efflux was quite variable, especially during the first half of the record, but neither the variability nor the mean changed in response to rain during the dry-moist period comparison (Table 2, Fig. 3). Later in the record, after several rain events, the variability decreased. 
Table 2. Statistics for soil temperature, soil surface flux, and $\delta^{13} \mathrm{C}$ of soil efflux $\left(\delta_{\mathrm{R}}\right)$ during the 5-day dry and moist periods shown in Fig. 3 . Values are shown for each chamber location separately. SD: standard deviation; CV: coefficient of variation expressed as a percentage. Number of measurements was $n=40$ for all cases (eight measurements per day at each location).

\begin{tabular}{lcrrrrrr}
\hline & & \multicolumn{3}{c}{ Dry period } & \multicolumn{3}{c}{ Moist period } \\
\cline { 3 - 8 } & Location & Mean & SD & CV & Mean & SD & CV \\
\hline Soil temperature $\left({ }^{\circ} \mathrm{C}\right)$ & 1 & 25.5 & 2.9 & 11.4 & 26.3 & 3.0 & 11.4 \\
& 2 & 25.6 & 2.1 & 8.2 & 26.4 & 2.4 & 9.1 \\
& 3 & 26.1 & 2.9 & 11.1 & 26.7 & 2.9 & 10.9 \\
\hline Soil surface flux $\left(\mu\right.$ mol m$\left.^{-2} \mathrm{~s}^{-1}\right)$ & 1 & 2.80 & 0.36 & 12.7 & 3.87 & 0.47 & 12.1 \\
& 2 & 2.63 & 0.23 & 8.9 & 3.66 & 0.44 & 11.9 \\
& 3 & 4.10 & 0.27 & 6.7 & 5.17 & 0.54 & 10.5 \\
\hline$\delta^{13} \mathrm{C}$ of soil surface flux $\left(\delta_{\mathrm{R}}, \% 0\right)$ & 1 & -25.8 & 0.3 & 1.0 & -25.6 & 0.4 & 1.5 \\
& 2 & -25.5 & 0.4 & 1.4 & -25.7 & 0.4 & 1.5 \\
& 3 & -24.9 & 0.2 & 0.9 & -24.9 & 0.4 & 1.6 \\
\hline
\end{tabular}

Rainfall did lead to systematic and sustained changes in belowground $\mathrm{CO}_{2}$ and its isotopic content (Fig. 4), but these changed together and thus $\delta_{\mathrm{J}}$ was not affected. The $\mathrm{CO}_{2}$ in the soil increased markedly following wetting, especially at depth. Pressure and wind speed varied with synoptic-scale atmospheric motion (Fig. 4). These quantities were only weakly related to changes in $C_{\mathrm{S}}$ and $\delta_{\mathrm{S}}$, which appeared to respond to wetting and its influence on diffusion and production rather than to ventilation. These data $\left(C_{\mathrm{S}}, \delta_{\mathrm{S}}\right)$ were combined with measurements of forest air $\left(C_{\mathrm{a}}, \delta_{\mathrm{a}}\right.$, Fig. 4$)$ to calculate time series of $\delta_{\mathrm{J}}$ at each depth (shown later) using Eq. (1).

There was strong diel variability in soil temperature (coefficient of variation, $\mathrm{CV}=8-11 \%$, Table 2) and soil efflux $(\mathrm{CV}=7-13 \%)$ but no diel variability in the isotopic content of soil efflux (CV<2\%; Fig. 5; Fig. S1). Normalized diel patterns were nearly identical during the dry and moist periods for all chambers (Fig. 5), despite the large increase in soil efflux following rain (Fig. S1, Table 2).

The theoretical expectation for fully diffusive mixing between the $\mathrm{CO}_{2}$ produced by respiration and forest air was supported by most of the observations from the chambers but not all of the gas wells (Fig. 6). The lower line shows a Keeling-type regression for the soil chamber inlets (Keeling, 1958). The intercept of the regression is shown and represents the $\delta^{13} \mathrm{C}$ of the $\mathrm{CO}_{2}$ added to forest air by soil respiration. This mixing occurs in the air above the soil via turbulence that dominates transport over diffusion by several orders of magnitude. A visual inspection of the chamber outlet data (Fig. 6) suggests that the data fall on the same mixing line, which would be an indication that the soil chambers did not cause appreciable perturbation in the diffusive efflux from the soil surface. The regression coefficients for the chamber inlet and outlet data were slightly but significantly different due to the large sample size examined here (Table 3). This conclusion was robust whether using the Keeling

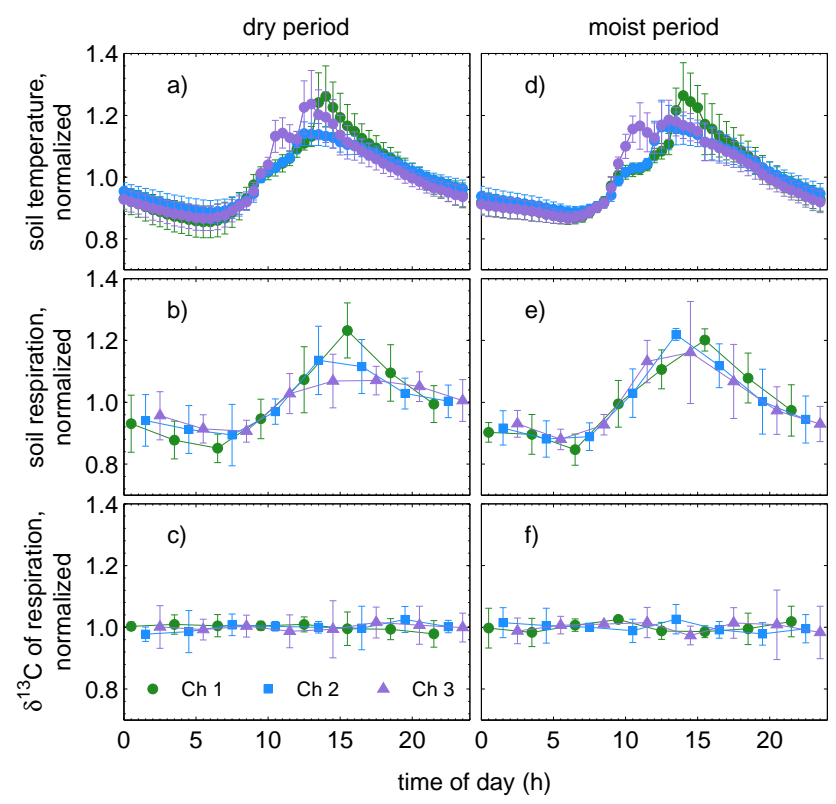

Figure 5. Mean (5-day) diel patterns of soil temperature $(5 \mathrm{~cm})$, soil surface flux, and $\delta^{13} \mathrm{C}$ of soil surface flux $\left(\delta_{\mathrm{R}}\right)$ during the dry (left) and moist (right) periods. Each time series was normalized by dividing by its 5-day mean. Data are shown for chambers 1, 2, and 3 separately (legend in c). A non-normalized version of this plot can be found in Appendix A.

mixing line as above or the Miller-Tans variant (Miller and Tans, 2003). The intercepts of regressions using the chamber outlet data were enriched relative to the inlet regression intercepts by $0.07 \pm 0.24 \%$ o to $0.59 \pm 0.15 \%$, depending on which chamber or which method was examined (Table 3). This was likely caused by a small perturbation in the diffusive flux within the chamber, while chamber $\mathrm{CO}_{2}$ increased during measurement. Regardless, this perturbation was minor relative to the diffusive enrichment within the soil. The 
Table 3. Calculations of the isotopic composition of $\mathrm{CO}_{2}$ of the soil efflux using the chamber inlet and outlet data separately. Regressions with the chamber inlet data highlight the $\delta^{13} \mathrm{C}$ of soil efflux from the forest in general, and those with the chamber outlet data highlight the $\delta^{13} \mathrm{C}$ of soil efflux within the chambers. Two variations of mixing relationship were examined, following Keeling (1958) and Miller and Tans (2003), either with all chamber data or subsets for each chamber. Analysis of covariance was performed on the pair highlighted in bold and the intercepts were statistically different (ANCOVA, $p<0.0001$ ). The standard errors of each slope or intercept are shown in parentheses. For the "difference" rows, the uncertainty in differences between pairs are shown in parentheses; $n=$ number of samples.

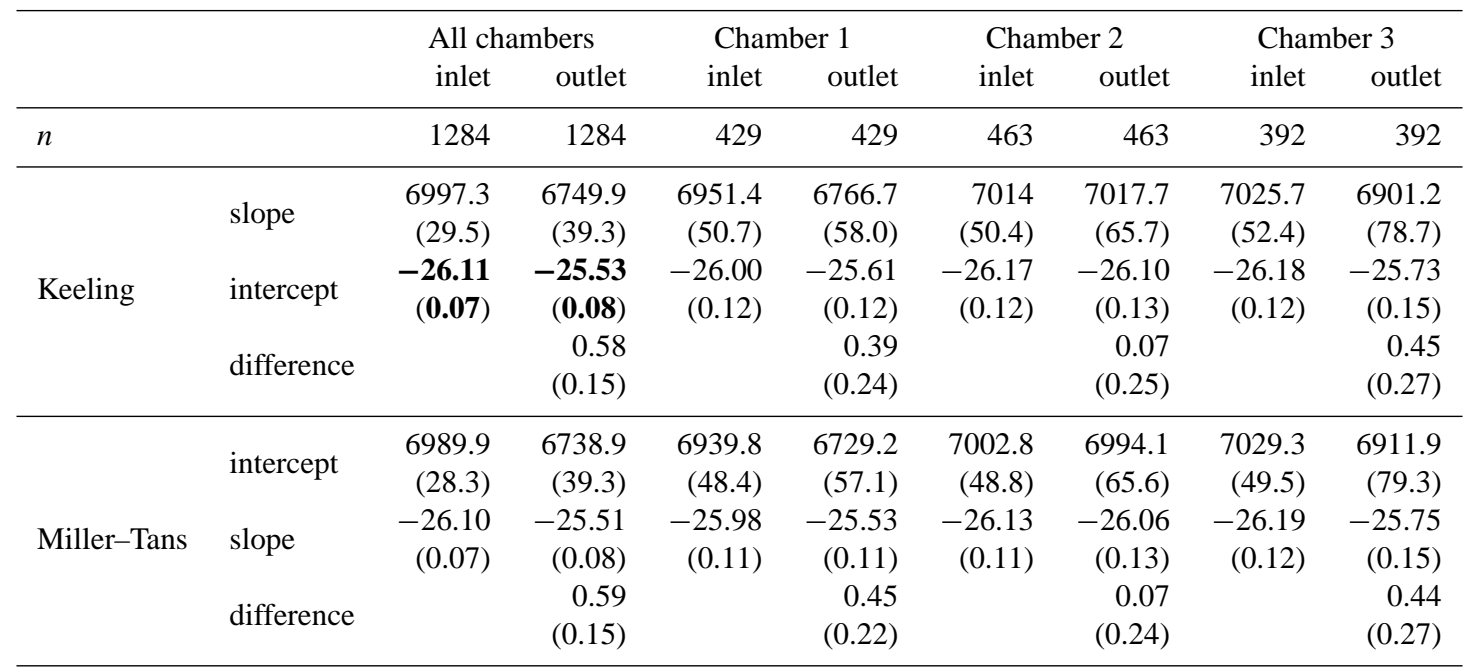

theoretical expectation for fully diffusive mixing between the $\mathrm{CO}_{2}$ produced by respiration (square) and forest air (circle) is shown by the solid line in Fig. 6. At depth $(10$ and $30 \mathrm{~cm})$, the gas well measurements conformed well to theory. At the $\mathrm{O} / \mathrm{A}$ interface, the data fell well below the expected diffusive mixing line. The $5 \mathrm{~cm}$ depth was intermediate between these.

Depth profiles of $\mathrm{CO}_{2}$ and $\delta^{13} \mathrm{C}$ of $\mathrm{CO}_{2}$ are shown in Fig. 7 for the dry and moist periods and compared with best-fit diffusion model results. In general the profiles conformed to model results, except for the shallow measurement depths (especially visible at the O/A interface in Fig. 7 b, d). There was diel temporal variability in $\mathrm{CO}_{2}$ and $\delta^{13} \mathrm{C}$ of $\mathrm{CO}_{2}$ (Fig. 4), but the diel changes were minor relative to changes with depth (Fig. 7). Following rain, there was a systematic and sustained increase in $\mathrm{CO}_{2}$ at all depths (Fig. 7a and c), which was concomitant with increased soil efflux (Figs. 3 and $\mathrm{S} 1)$. The $\delta^{13} \mathrm{C}$ of $\mathrm{CO}_{2}$ is generally nonlinearly related to $\mathrm{CO}_{2}$ in the soil, and at higher $\mathrm{CO}_{2}$ there is only a small change expected in $\delta^{13} \mathrm{C}$ (see Fig. 5 in Bowling et al., 2009). This is consistent with little change observed following rain in $\delta^{13} \mathrm{C}$ of $\mathrm{CO}_{2}$ in the soil pore space $\left(\delta_{\mathrm{S}}, \mathrm{Fig} .7 \mathrm{~b}, \mathrm{~d}\right)$. Neither the $\delta^{13} \mathrm{C}$ of the soil efflux ( $\delta_{\mathrm{R}}$, measured with chambers) nor the $\delta^{13} \mathrm{C}$ of production within the soil $\left(\delta_{\mathrm{J}}\right.$, calculated from gas well data) changed between the dry and moist periods (Fig. 7b, d; Table 4). The $\delta^{13} \mathrm{C}$ of $\mathrm{CO}_{2}$ in the soil pore space was always more enriched than the $\delta^{13} \mathrm{C}$ of soil efflux $\left(\delta_{\mathrm{R}}\right)$ or production within the soil $\left(\delta_{\mathrm{J}}\right)$, and especially so closer to the surface.

The $\delta_{\mathrm{J}}$ varied systematically with depth, and at 10 and $30 \mathrm{~cm}$ was very close to $\delta_{\mathrm{R}}$ as expected from diffusion the-

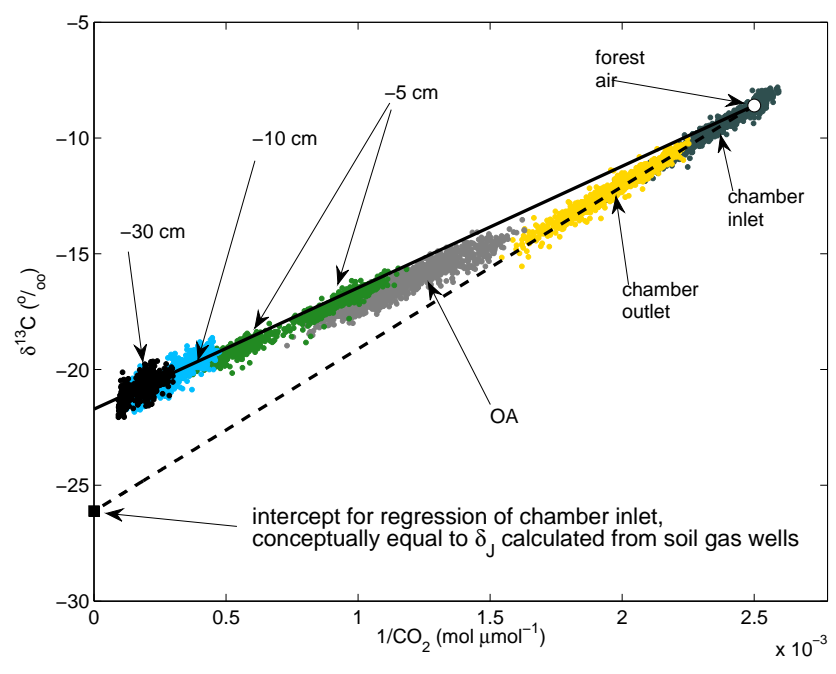

Figure 6. Relationships between $\delta^{13} \mathrm{C}$ and $1 / \mathrm{CO}_{2}$ measured at the chamber inlet and outlet and in the soil pore space at four depths; all data from all locations are shown for the 2-month experiment. The dashed line is a regression of the chamber inlet data $\left(\delta^{13} \mathrm{C}=6997 / \mathrm{CO}_{2}-26.1 \%\right.$; $n=1284$; standard error of intercept $=0.07 \%$ ) . The solid line represents the expected diffusive mixing relationship and was drawn between the $y$ intercept (shifted $4.4 \%$ above the regression intercept) and an arbitrary indicator of forest air (white circle, $-8.6 \%$ and $\left.1 /\left(400 \mu \mathrm{mol} \mathrm{mol}^{-1}\right)\right)$. Note the chamber inlet data are actual measurements of forest air and illustrate its variability. Note also that the data from the O/A interface and $5 \mathrm{~cm}$ depth fall between these lines due to the experimental artifact described in the text. 
Table 4. Statistics for $\delta^{13} \mathrm{C}$ of soil surface flux $\left(\delta_{\mathrm{R}} \%\right.$ o $)$ and $\delta^{13} \mathrm{C}$ of production $\left(\delta_{\mathrm{J}}, \%\right.$ o over the full 2-month measurement period and for the dry and moist periods. Data from all chambers were combined. SD: standard deviation; $n=$ number of measurements. Overall frequency distributions and statistics for 2-month period are shown in Fig. 8. Letters indicate means that were significantly different $(p<0.0001$, Tukey's honest significant difference test).

\begin{tabular}{|c|c|c|c|c|c|c|c|c|c|c|}
\hline & \multirow[b]{2}{*}{ Depth } & \multicolumn{3}{|c|}{ All data } & \multicolumn{3}{|c|}{ Dry period } & \multicolumn{3}{|c|}{ Moist period } \\
\hline & & Mean & SD & $n$ & Mean & SD & $n$ & Mean & SD & $n$ \\
\hline$\delta^{13} \mathrm{C}$ of soil surface flux $\left(\delta_{\mathrm{R}}, \% o\right)$ & surface & $-25.6^{\mathrm{d}}$ & 1.1 & 1284 & $-25.4^{\mathrm{c}}$ & 1.1 & 117 & $-25.4^{\mathrm{c}}$ & 1.3 & 112 \\
\hline$\delta^{13} \mathrm{C}$ of production & $\begin{array}{l}\mathrm{O} / \mathrm{A} \text { interface } \\
-5 \mathrm{~cm} \\
-10 \mathrm{~cm} \\
-30 \mathrm{~cm}\end{array}$ & $\begin{array}{l}-27.2^{\mathrm{a}} \\
-26.2^{\mathrm{b}} \\
-26.0^{\mathrm{c}} \\
-26.0^{\mathrm{c}}\end{array}$ & $\begin{array}{l}0.6 \\
0.3 \\
0.3 \\
0.3\end{array}$ & $\begin{array}{l}1050 \\
1021 \\
1153 \\
1022\end{array}$ & $\begin{array}{l}-27.5^{\mathrm{a}} \\
-26.2^{\mathrm{b}} \\
-26.0^{\mathrm{b}} \\
-26.0^{\mathrm{b}}\end{array}$ & $\begin{array}{l}0.8 \\
0.4 \\
0.4 \\
0.3\end{array}$ & $\begin{array}{l}114 \\
110 \\
113 \\
111\end{array}$ & $\begin{array}{l}-27.2^{\mathrm{a}} \\
-26.2^{\mathrm{b}} \\
-26.0^{\mathrm{b}} \\
-26.0^{\mathrm{b}}\end{array}$ & $\begin{array}{l}0.5 \\
0.2 \\
0.4 \\
0.3\end{array}$ & $\begin{array}{l}112 \\
100 \\
104 \\
107\end{array}$ \\
\hline
\end{tabular}
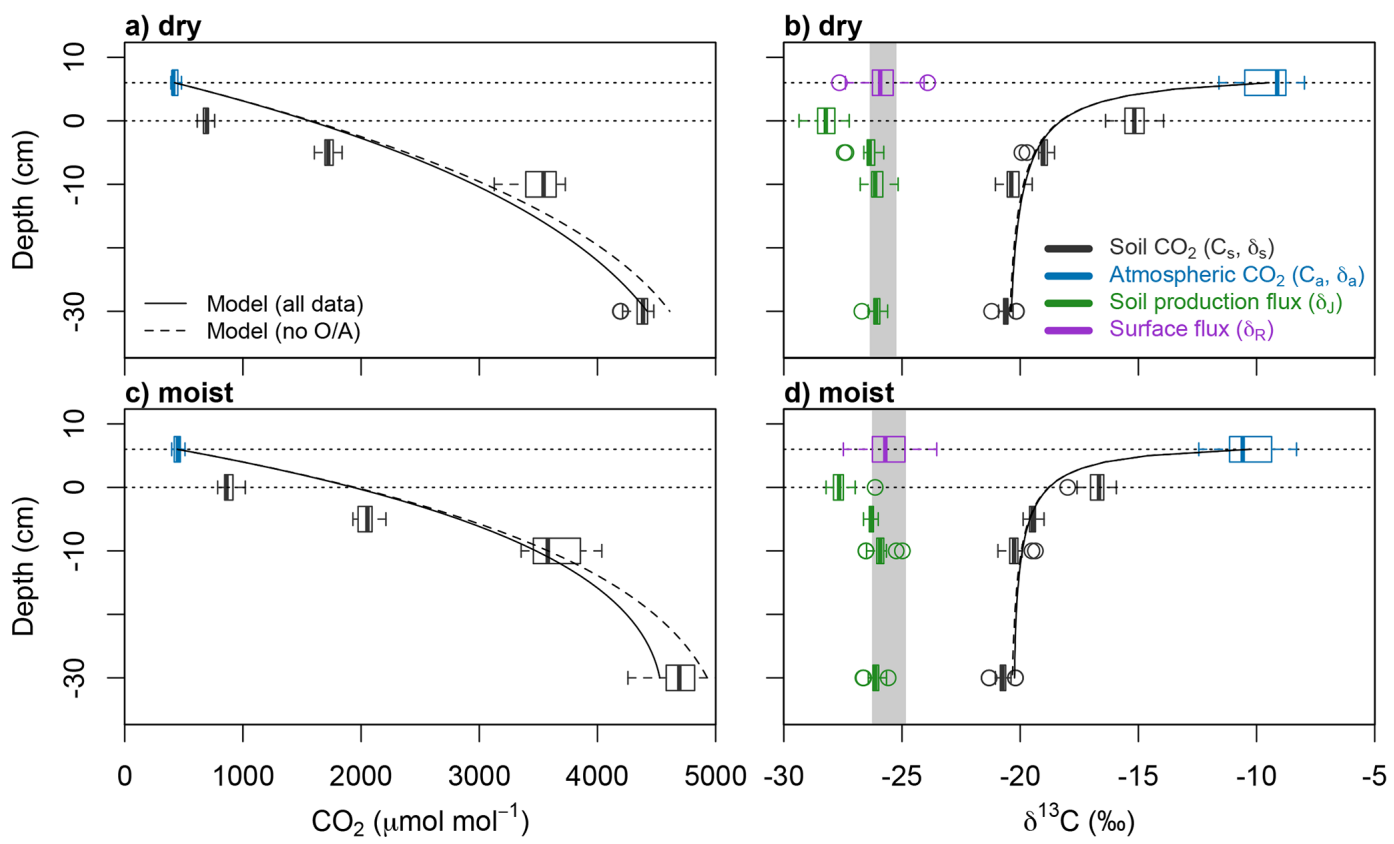

Figure 7. Measured profiles of soil pore space and atmospheric $\mathrm{CO}_{2}, \delta^{13} \mathrm{C}$ of soil pore space and atmospheric $\mathrm{CO}_{2}$ for the 5-day dry and moist periods for chamber 1 (other chambers were similar). Atmospheric measurements (blue) were made at the inlet of the automated chamber. These are compared to the $\delta^{13} \mathrm{C}$ of soil surface flux $\left(\delta_{\mathrm{R}}\right.$, purple) measured by the automated chamber, and to the $\delta^{13} \mathrm{C}$ of the $\mathrm{CO}_{2}$ produced by respiration $\left(\delta_{\mathrm{J}}\right.$, green, calculated from the measurements in black and blue using Eq. 1). Box and whisker diagrams are used to indicate statistical distributions using the median (central line) and 25th and 75th percentiles (box edges). Data exceeding the interquartile range by a factor of 1.5 are denoted as outliers (circles). The gray rectangles in the right panels are shown at the 25 th and 75 th percentiles for $\delta_{\mathrm{R}}$ (purple), to facilitate comparison with $\delta_{\mathrm{J}}$ (green). Lines show the results of the best-fit diffusion model (see text) compared to either all measurement depths (solid line) or (dashed) excluding the O/A interface $(0 \mathrm{~cm})$. Horizontal dotted lines at 0 and $6 \mathrm{~cm}$ indicate the $\mathrm{O} / \mathrm{A}$ interface and the top of the $\mathrm{O}$ horizon, respectively.

ory (Davidson, 1995; shading in Fig. 7b, d). Note, however, that $\delta_{\mathrm{R}}$ and $\delta_{\mathrm{J}}$ were statistically distinguishable in most cases (Table 4). The $\delta^{13} \mathrm{C}$ of $\mathrm{CO}_{2}$ in the soil pore space was more enriched than expected based on best-fit diffusion model results at the O/A interface (compare to model lines in Fig. 7b, d). This was true when model results were compared to all measurement depths (solid line) or (dashed) excluding the $\mathrm{O} / \mathrm{A}$ interface $(0 \mathrm{~cm})$. The $\delta \mathrm{J}$ at $5 \mathrm{~cm}$ and especially at the $\mathrm{O} / \mathrm{A}$ interface was more negative than the $\delta^{13} \mathrm{C}$ of the soil efflux. This pattern was maintained for the full duration of the study. Frequency distributions of all measurements of $\delta_{\mathrm{R}}$ and $\delta_{\mathrm{J}}$ are shown in Fig. 8. There was much higher variability in $\delta_{\mathrm{R}}$ than in $\delta_{\mathrm{J}}$, but this variability was not related to any measured environmental parameters.

The mean $\delta^{13} \mathrm{C}$ of soil efflux measured with the chambers was very similar to the mean signature of whole-forest respiration $\left(\delta_{\mathrm{F}}\right.$, Fig. 8, Bowling et al. 2014). The $\delta_{\mathrm{R}}$ was very similar to the mean $\delta_{\mathrm{J}}$ at 5,10 , and $30 \mathrm{~cm}$ but not at the $\mathrm{O} / \mathrm{A}$ 

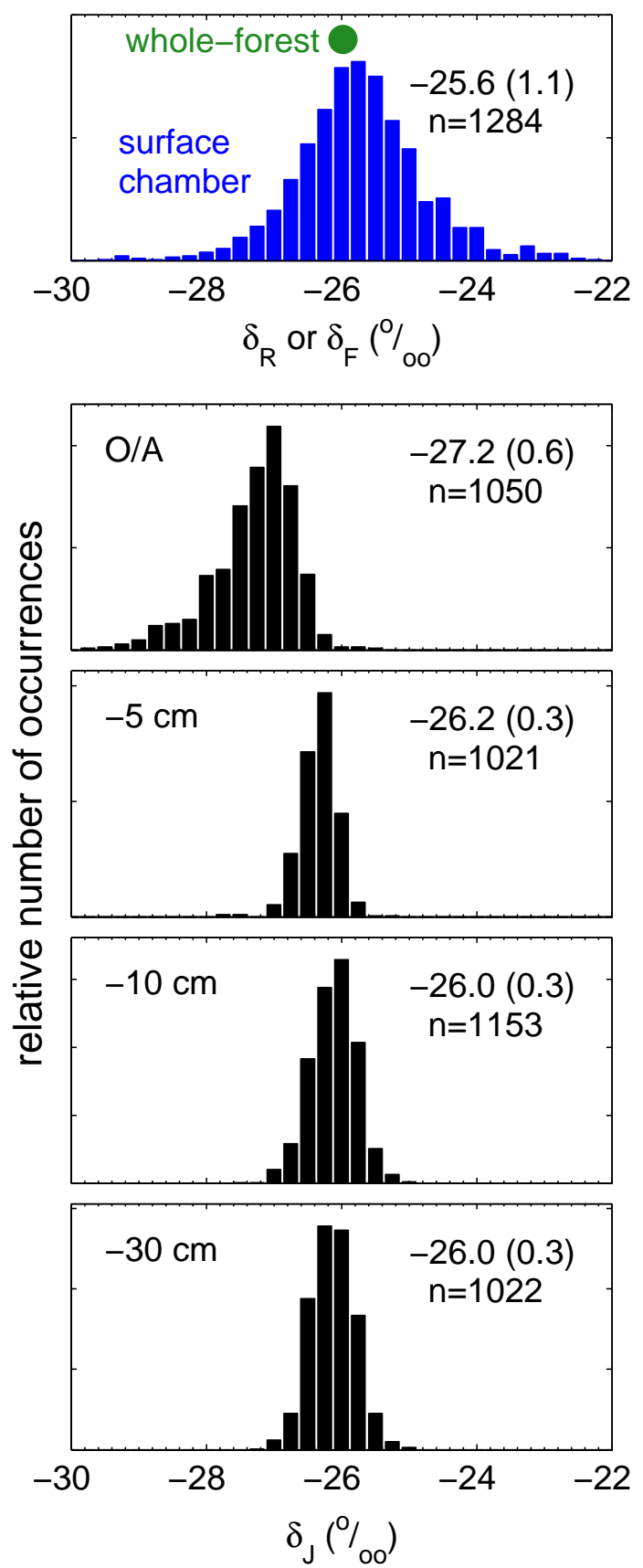

Figure 8. Frequency distributions of all measurements at all locations over the 2-month duration of the experiment of $\delta^{13} \mathrm{C}$ of soil surface flux $\left(\delta_{\mathrm{R}}\right)$ measured by automated chambers and $\delta^{13} \mathrm{C}$ of the $\mathrm{CO}_{2}$ produced by respiration $\left(\delta_{\mathrm{J}}\right)$ at each depth. Numbers on the plots are means, standard deviations, and sample size. Also shown in the top panel (circle) is the mean for the $\delta^{13} \mathrm{C}$ of whole-forest respiration $\left(\delta_{\mathrm{F}}\right)$ determined from measurements of forest air for this time period reported by Bowling et al. (2014) (the uncertainty is smaller than the symbol). Deviations in the mean of $\delta_{\mathrm{J}}$ at the $\mathrm{O} / \mathrm{A}$ interface from $\delta_{\mathrm{R}}$ were caused by experimentally induced advection, as discussed in the text. interface, whose distribution was highly negatively skewed (Fig. 8). The mean $\delta_{\mathrm{R}}$ and $\delta_{\mathrm{J}}$ at depth differed minimally but the differences were statistically significant due to the large number of samples (Table 4). This pattern was observed for the full data set (Fig. 8) and also during the dry and moist periods (Table 4 ). In all cases the soil efflux $\delta_{\mathrm{R}}$ was only enriched by a small amount ( 0.4 to $0.6 \%$ ) relative to $\delta_{\mathrm{J}}$ at 10 and $30 \mathrm{~cm}$ depth (Table 4). Due to the large number of samples, we do not interpret these small statistical differences as providing particularly meaningful information about ecological processes, with the exception of the O/A interface and $5 \mathrm{~cm}$ depths (as will be discussed later).

\section{Discussion}

Biological respiration is highly responsive to temperature (Davidson and Janssens, 2006), and it is well-established that the process rate of respiration and the soil efflux both vary with temperature on diel (Savage et al., 2013) and seasonal (Jassal et al., 2005) timescales. Our observations of soil efflux and soil temperature also showed correlated diel variability as expected (Figs. 3, 5 and S1). Several studies have reported diel variation in the $\delta^{13} \mathrm{C}$ of the soil efflux (Bahn et al., 2009; Kodama et al., 2008; Marron et al., 2009), but in our case there was no diel variation in the $\delta^{13} \mathrm{C}$ of soil respiration (neither $\delta_{\mathrm{R}}$, Fig. 5 nor $\delta_{\mathrm{J}}$, Fig. 7). The potential biological mechanisms that would lead to diel variation in $\delta^{13} \mathrm{C}$ of respiration have been recently reviewed (Werner and Gessler, 2011) and include variation in respiratory substrate, isotopic fractionation, and/or changes in relative amounts of component fluxes such as autotrophic (rhizospheric) and heterotrophic respiration. There is compelling evidence for a short-term linkage between photosynthesis and belowground respiration (Kuzyakov and Gavrichkova, 2010), almost certainly mediated by the roots and their symbionts (Hopkins et al., 2013; Savage et al., 2013). Several studies have highlighted isotopic signals in respiration from the soil or whole forests that appear to be influenced by photosynthetic response to humidity or water availability (see reviews by Bowling et al., 2008; Brüggemann et al., 2011), which might be expected to lead to diel changes in $\delta^{13} \mathrm{C}$ of soil efflux. However, purely physical processes of heat conduction and diffusive transport can also lead to diel variability in soil efflux rate and its time-lagged correlation with soil temperature (Phillips et al., 2011) and in the $\delta^{13} \mathrm{C}$ of soil respiration (Bowling et al., 2011; Moyes et al., 2010). To date these physical processes have been underappreciated by the soil ecological community. It is possible that strictly biological interpretations of diel variation in $\delta^{13} \mathrm{C}$ of soil respiration are too simplistic. Based on these results we reject our first hypothesis - there appears to be no diel variation in $\delta^{13} \mathrm{C}$ of soil efflux at our study forest. We cannot explain why others have found such variation and we have not. 
Rainfall wets the soil from the top down and in previously dry soils can markedly increase overall respiration rate (Borken and Matzner, 2009). Presumably this effect is dominated by heterotrophic activity, with changes in microbial community composition and function (Fierer et al., 2003; Placella et al., 2012), but the rhizosphere (and rhizosphere symbionts) can respond to wetting as well. This may lead to the priming of decomposition and nutrient mineralization (Dijkstra and Cheng, 2007) as well as enhanced activity by root symbionts (Querejeta et al., 2003). Such processes can be directly mediated via plant roots. For example, watering soil on only one side of a ponderosa pine tree enhances soil $\mathrm{CO}_{2}$ efflux on the dry side (Irvine et al., 2005).

There are no known general patterns for carbon isotopic response to wetting in the soil $\mathrm{CO}_{2}$ efflux. Immediate effects of rain involve decreased gas diffusivity and solubilization of existing pore space $\mathrm{CO}_{2}$ in water (Gamnitzer et al., 2011), and after hours to days, changes in biological processes as described above. All might be expected to have isotopic effects. Wingate et al. (2010) found in a maritime pine forest that $\delta^{13} \mathrm{C}$ of the soil efflux varied slowly over several months by $\sim 2 \%$, becoming most enriched in midsummer, but there was no clear change following frequent wetting events. A root exclusion experiment demonstrated that there is minimal variability in $\delta^{13} \mathrm{C}$ of microbial respiration, but there is variability in $\delta^{13} \mathrm{C}$ of autotrophic respiration related to drought, suggesting a linkage to photosynthesis (Risk et al., 2012). Lab incubation experiments have shown no change in $\delta^{13} \mathrm{C}$ of heterotrophic respiration over a broad moisture range (Phillips et al., 2010). In some semiarid ecosystems rain pulses and irrigation experiments have led to 6-8\%o isotopic changes (both enrichment and depletion) in $\delta^{13} \mathrm{C}$ of soil efflux (Powers et al., 2010; Unger et al., 2012). In our case, there was no change in $\delta_{\mathrm{R}}$ or $\delta_{\mathrm{J}}$ over 2 months despite several occurrences of rain (Figs. 3 and 7). The first rain event shown increased the soil efflux by up to $39 \%$ (Table 3, Fig. 3), so it is highly likely that heterotrophic respiration increased. The $\delta^{13} \mathrm{C}$ of the soil efflux was highly variable but $\delta_{\mathrm{J}}$ was quite consistent and the means of both measures were nearly invariant over the study (Fig. 8). Hence there appears to be no generalizable pattern in the $\delta^{13} \mathrm{C}$ of soil efflux following wetting, and we reject our second hypothesis. We do not know why others have found such high variation in $\delta^{13} \mathrm{C}$ of soil efflux in response to wetting while we did not.

Several studies have interpreted variation in isotope content of soil respiration in the context of partitioning autotrophic and heterotrophic respiration (see reviews by Kuzyakov, 2006; Paterson et al., 2009). It is certain that both respiratory processes were occurring in our system, but there was no diel change in $\delta_{\mathrm{R}}$ or $\delta_{\mathrm{J}}$ (Figs. 5 and 7) and no change in either following rain. Isotopic transformations of carbon in the plant-soil-microbial system are quite complex (Brüggemann et al., 2011), and often the isotopic difference in autotrophic and heterotrophic respiration is too small to be useful in distinguishing between them (Formánek and Ambus,
2004; Kuzyakov, 2006). These results suggest that natural abundance carbon isotope studies in $C_{3}$ ecosystems are not likely to be a generally useful tool for partitioning of soil respiration. We recommend that future isotopic studies focused on partitioning the components of soil respiration take advantage of recent major advances in isotopic labeling (Carbone et al., 2007; Epron et al., 2012; Högberg et al., 2008).

Several studies have shown that trace gas transport in porous soils in a variety of ecosystems is subject to ventilation by wind or pressure pumping (e.g., Flechard et al., 2007; Fujiyoshi et al., 2010; Maier et al., 2010; SánchezCañete et al., 2013) and even by thermal convection (Ganot et al., 2014). When diffusion initially dominates transport and a ventilation event follows, there should be a readily detectible isotopic effect as ventilation removes some of the small pool of diffusively enriched $\mathrm{CO}_{2}$ within the soil (as described in Fig. 1). We have previously reported the isotopic effect of ventilation within the snowpack at the Niwot Ridge forest (Bowling and Massman, 2011). In that study, a sustained wind event decreased the $\mathrm{CO}_{2}$ within the upper soil by $30 \%$ (1000 $\mu \mathrm{mol} \mathrm{mol}^{-1}$ decrease), even though the soil was covered by a $\sim 1 \mathrm{~m}$ deep snowpack. The bulk fluid flow likely penetrates only a few centimeters into the surface of a snowpack (Clifton et al., 2008), but trace gas mole fractions can change substantially deeper following the perturbation in diffusion (Seok et al., 2009). For these reasons we anticipated that in summer, without the physical barrier of a snowpack, the isotopic effect of ventilation within soils would be quite strong.

The passage of weather systems in our study led to expected variation in barometric pressure and wind speed (Fig. 4), with concomitant variation in soil $\mathrm{CO}_{2}$ as deep as $30 \mathrm{~cm}$ (Fig. 4). However, the variability in soil $\mathrm{CO}_{2}$ was fairly minor (compare Fig. 4 to dramatic changes in Fig. 3 of Sánchez-Cañete et al., 2013), and soil $\mathrm{CO}_{2}$ was not correlated with wind speed, friction velocity, or pressure. Large changes in soil $\mathrm{CO}_{2}$ were related to rain events (Fig. 3) as gas diffusivity of the bulk soil system changed with soil moisture content. There were no discernible isotopic effects associated with pressure variation (not shown, but note the very limited variation in $\delta_{\mathrm{R}}, \delta_{\mathrm{S}}$ and $\delta_{\mathrm{J}}$ over the full experiment in Fig. 7 and the adherence of 10 and $30 \mathrm{~cm}$ depths to the upper (diffusive) mixing line in Fig. 6). Hence, we find no isotopic evidence for pressure-induced ventilation of the deep soil $(10 \mathrm{~cm}$ or greater below the $\mathrm{O} / \mathrm{A}$ interface) in summer at the Niwot Ridge forest and thus reject our third hypothesis (but with a caveat that will be discussed later).

This result contrasts directly with observations under the snowpack at the same forest (Bowling and Massman, 2011), where large $(30 \%)$ changes in $\mathrm{CO}_{2}$ in the upper soil were caused by wind. This can be explained by considering the medium directly above the soil surface as a boundary condition for the soil diffusive system. Due to the high permeability of the snowpack, wind perturbations to the diffusive gradient cause large changes in $\mathrm{CO}_{2}$ just above the soil surface 
(at the bottom of the snowpack). In summer, even though $\mathrm{CO}_{2}$ does change in forest air above the soil, this variation is minor relative to the vertical gradient in $\mathrm{CO}_{2}$ within the soil (Fig. 7a, b), and so wind does not affect the soil surface boundary condition appreciably. This result, of course, is dependent on the magnitude of the total production of $\mathrm{CO}_{2}$. At very low production rates, variability in forest air $\mathrm{CO}_{2}$ at the soil surface would be much larger relative to the smaller vertical gradients associated with low production. This physical effect can influence diffusion to markedly affect diel variation in the $\delta^{13} \mathrm{C}$ of the soil gas system (Bowling et al., 2011; Moyes et al., 2010).

Our study confirms theoretical expectations of gas transport in the biophysical soil system but also highlights a limitation of diffusion-only models in the context of experimentally induced advection. A very important aspect of existing theory asserts that at steady state the $\delta^{13} \mathrm{C}$ of soil efflux matches the $\delta^{13} \mathrm{C}$ of biological production but both differ from the $\delta^{13} \mathrm{C}$ of $\mathrm{CO}_{2}$ within the soil (Cerling et al., 1991; Davidson, 1995). Our results are in agreement - extensive measurements of $\delta_{\mathrm{R}}$ using soil chambers were consistent with those of $\delta_{\mathrm{J}}$ from gas wells at 10 and $30 \mathrm{~cm}$ depths over the entire 2-month study ( $n>1000$ in each case; Fig. 8). These observations of $\delta_{\mathrm{R}}$ and $\delta_{\mathrm{J}}$ also match the $\delta^{13} \mathrm{C}$ of whole-forest respiration obtained from measurements of forest air (Fig. 8, top panel), providing confidence that the entire gas transport system is primarily diffusive and well described by present theoretical understanding.

However, the $\delta_{\mathrm{J}}$ observed at the $\mathrm{O} / \mathrm{A}$ interface and at $5 \mathrm{~cm}$ depth was both more negative than $\delta_{\mathrm{R}}$ (Figs. 7 and 8; Table 4$)$. There are two possible ways to interpret this difference. First, natural ventilation of the near-surface soils by wind and/or pressure could cause mixing of $\mathrm{CO}_{2}$ in the profile with $\mathrm{CO}_{2}$ in air, which would decrease $\mathrm{CO}_{2}$ and make $\delta^{13} \mathrm{C}$ of $\mathrm{CO}_{2}$ less negative at the $\mathrm{O} / \mathrm{A}$ interface and the $5 \mathrm{~cm}$ depth. This is consistent with observations of $C_{\mathrm{S}}$ and $\delta_{\mathrm{S}}$ (black boxes in Fig. 7) and with the deviation from the upper diffusive line (Fig. 6) at these depths. However, if persistent natural ventilation were occurring, the $\delta_{\mathrm{R}}$ measured independently using the chambers (purple in Fig. 7) would match $\delta_{\mathrm{J}}$ at the $\mathrm{O} / \mathrm{A}$ interface, since that gas diffuses directly into the chambers - but this did not occur. Hence a second interpretation is most likely correct: the pumping of gas from the shallower soil gas wells to transport it to the analyzer caused artificial mixing of forest air with soil air by advection. Observations of $\delta_{\mathrm{J}}$ from the 10 and $30 \mathrm{~cm}$ depths matched $\delta_{\mathrm{R}}$ from the chambers (Figs. 7 and 8), and the mixing at these depths was consistent with diffusion theory (Figs. 1 and 6) and best-fit diffusion model results (Fig. 7). Mixing of gas at these depths due to pumping likely occurred, but the vertical gradients of $\mathrm{CO}_{2}$ and especially $\delta^{13} \mathrm{C}$ of $\mathrm{CO}_{2}$ (Fig. 7) were much smaller at these depths, and thus $\delta_{\mathrm{J}}$ was not affected. Future studies that seek to examine the near-surface influence of atmospheric turbulence on soil gas transport must strive to minimize artifacts due to sampling. This could be facilitated by minimizing the amount of soil gas required for sampling (Moyes and Bowling, 2013) or by developing a sampling design which allows a larger soil volume to be sampled without disturbance to diffusion (e.g., Parent et al., 2013).

The $\delta^{13} \mathrm{C}$ of the soil efflux measured in chambers was considerably more variable than the $\delta^{13} \mathrm{C}$ of production observed using the gas wells (Fig. 8), but their means were quite similar. The soil efflux was roughly normally distributed, but at depth the distributions for $\delta_{\mathrm{J}}$ were more peaked (high kurtosis). We examined a number of possible reasons to explain the higher variability in $\delta^{13} \mathrm{C}$ of the soil efflux. We could find no relation between variability in $\delta_{\mathrm{R}}$ and statistical metrics (mean, variance, rate of change, friction velocity) of wind speed or barometric pressure. Variability was also unrelated to sunlight, humidity, soil temperature, soil moisture, soil efflux, and $\mathrm{CO}_{2}$ mole fraction increase during chamber closure. This contrasts with other studies that have shown correlations between soil $\mathrm{CO}_{2}$ and/or soil efflux with these environmental forcing mechanisms (e.g., Davidson et al., 1998; Roland et al., 2015; Sánchez-Cañete et al., 2013; Savage et al., 2013; Subke et al., 2003), highlighting the variability in these processes across the landscape.

The $\delta^{13} \mathrm{C}$ of soil air in upper horizons is susceptible to advection due to natural weather dynamics and to methodological artifacts. Using alternative methods Goffin et al. (2014) showed that $\delta^{13} \mathrm{C}$ of $\mathrm{CO}_{2}$ in a highly permeable litter layer was indeed affected by turbulence. Given our pumping artifact, we cannot exclude the possibility of pressure-induced transport near the soil surface using our gas well data. In fact, the much higher variability in $\delta^{13} \mathrm{C}$ of soil efflux relative to $\delta_{\mathrm{J}}$ from the gas wells at 10 and $30 \mathrm{~cm}$ depths (Fig. 8) may provide evidence for pressure-induced variation in gas transport near the surface. Shearing of wind by forest canopy elements induces variability in magnitude and spectral composition of wind velocity and momentum flux with length scales of a similar size to the spacing of canopy elements (Amiro, 1990; Tóta et al., 2012; Vickers and Thomas, 2014). This is likely to induce pressure variation within the soil with similar horizontal length scales that vary with wind speed, direction, and surface roughness (Albert and Hawley, 2002; Baldocchi and Meyers, 1991; Staebler and Fitzjarrald, 2005). Conservation of mass requires that, on average, $\delta_{\mathrm{R}}$ should match $\delta_{\mathrm{J}}$ (as it does at 10 and $30 \mathrm{~cm}$ depths; Fig. 8), but the presence of such dynamic fluid forcing could lead to transient spatial variability in $\delta^{13} \mathrm{C}$ of efflux measured in the chambers (as observed with higher variability in $\delta_{\mathrm{R}}$ than $\delta_{\mathrm{J}}$ ). Hence we cannot fully reject our third hypothesis, which states that pressure variation leads to the ventilation of the soil. We have shown strong evidence that ventilation does not occur at 10 and $30 \mathrm{~cm}$ depths, but our data cannot exclude the possibility of ventilation of the shallower soil. 


\section{Conclusions}

We have examined the isotopic composition of $\mathrm{CO}_{2}$ produced by the respiration of soil organisms with an extensive data set utilizing three independent methods - soil surface chambers, soil pore gas wells, and forest air inlets - and compared these results with a steady-state diffusion model. Results were consistent between the three methods and conformed well to physical theory of diffusive transport in soils. This concordance provides strong evidence that experimental artifacts associated with chamber-soil pressure gradients were absent in our soil chambers. However, we have shown that the more negative values for the $\delta^{13} \mathrm{C}$ of $\mathrm{CO}_{2}$ produced within the soil that were derived from shallower soil pore measurements were inconsistent with best-fit diffusion model results and with soil chamber observations and thus must have been artificially induced by pumping.

From these observations we reject two of our three hypotheses. We found no evidence for diel variation in the $\delta^{13} \mathrm{C}$ of the soil efflux or of the $\mathrm{CO}_{2}$ produced within the soil. We found no evidence that rain leads to changes in $\delta^{13} \mathrm{C}$ of the soil efflux. We were unable to explain why others have found these patterns while we did not. Pressure-induced ventilation of the soil did not occur at our deepest soil gas measurement depths, but the high variability in $\delta^{13} \mathrm{C}$ of the soil efflux relative to $\mathrm{CO}_{2}$ produced at depth suggests that there may be sporadic ventilation at the shallower depths. We note that our results contrast with several other studies, which demonstrate that there is high variability in the biophysical forcing of soil gas transport across Earth's surface.
This study provides evidence that natural abundance carbon isotopes in $\mathrm{C}_{3}$ ecosystems are not a generally useful tool for partitioning between autotrophic and heterotrophic respiration; this is in agreement with earlier studies (Formánek and Ambus, 2004; Kuzyakov, 2006). We recommend that future isotopic studies that seek to disentangle the components of soil respiration take advantage of powerful recent advances in isotopic labeling (Carbone et al., 2007; Epron et al., 2012; Högberg et al., 2008). 


\section{Appendix A}

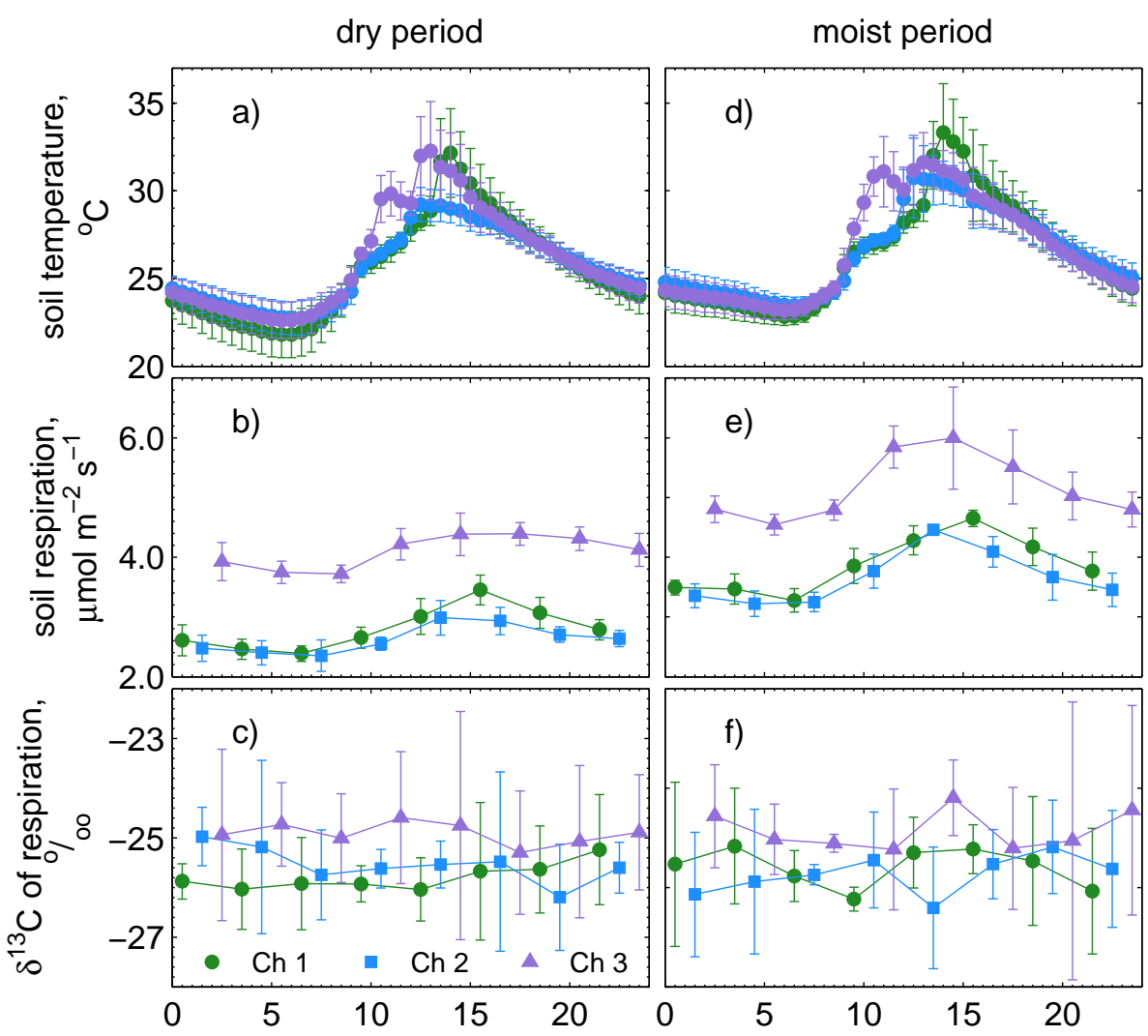

Figure A1. Mean (5-day) diel patterns of soil temperature $(5 \mathrm{~cm})$, soil surface flux, and $\delta^{13} \mathrm{C}$ of soil surface flux $\left(\delta_{\mathrm{R}}\right)$ during the dry (left) and moist (right) periods. Data are shown for chambers 1,2, and 3 separately (legend in c). Normalized versions of these plots are shown in Fig. 5 of the main article. 
Author contributions. D. R. Bowling designed the experiments, built the instrumentation and made the measurements. J. E. Egan conducted soil gas transport modeling, and S. J. Hall performed statistical analyses. All coauthors contributed to the scientific interpretation. D. R. Bowling prepared the manuscript with contributions from coauthors.

Acknowledgements. All data from this study are available for collaborative use by anyone interested; contact D. R. Bowling for information on data access (david.bowling@utah.edu). Thanks to J. Knowles and A. Chan for outstanding field assistance, to N. Nickerson and T. Huth for help with modeling, to T. Cerling and G. Maurer for several thoughtful discussions, to L. Wingate for loaning a prototype soil chamber, and to E. Grote for helping with chamber automation. We are grateful to S. Burns and P. Blanken for providing weather data from the Niwot AmeriFlux tower. This work was supported by the U.S. Department of Energy, Office of Science, Office of Biological and Environmental Research, Terrestrial Ecosystem Science Program under Award Numbers DE-SC0005236 and DE-SC0010625. D. R. Bowling and S. J. Hall were also supported by NSF EPSCoR grant EPS 1208732 awarded to Utah State University, as part of the State of Utah EPSCoR Research Infrastructure Improvement Award. J. E. Egan is grateful for additional support from a Research-in-Residence Award from the Inter-university Training in Continental-scale Ecology Project, NSF EF-1137336.

Edited by: J.-A. Subke

\section{References}

Albert, M. R. and Hawley, R. L.: Seasonal changes in snow surface roughness characteristics at Summit, Greenland: implications for snow and firn ventilation, Ann. Glaciol., 35, 510-514, 2002.

Amiro, B. D.: Drag coefficients and turbulence spectra within three boreal forest canopies, Bound.-Lay. Meteorol., 52, 227-246, doi:10.1007/BF00122088, 1990.

Amundson, R., Stern, L., Baisden, T., and Wang, Y.: The isotopic composition of soil and soil-respired $\mathrm{CO}_{2}$, Geoderma, 82, 83114, 1998.

Angert, A., Yakir, D., Rodeghiero, M., Preisler, Y., Davidson, E. A., and Weiner, T.: Using $\mathrm{O}_{2}$ to study the relationships between soil $\mathrm{CO}_{2}$ efflux and soil respiration, Biogeosciences, 12, 2089-2099, doi:10.5194/bg-12-2089-2015, 2015.

Aubrey, D. P. and Teskey, R. O.: Root-derived CO2 efflux via xylem stream rivals soil $\mathrm{CO}_{2}$ efflux, New Phytol., 184, 35-40, 2009.

Bahn, M., Schmitt, M., Siegwolf, R., Richter, A., and Brüggemann, N.: Does photosynthesis affect grassland soil-respired $\mathrm{CO}_{2}$ and its carbon isotope composition on a diurnal timescale?, New Phytol., 182, 451-460, 2009.

Baldocchi, D. D. and Meyers, T. P.: Trace gas exchange above the floor of a deciduous forest 1 . Evaporation and $\mathrm{CO}_{2}$ efflux, J. Geophys. Res., 96, 7271-7285, 1991.

Ballantyne, A. P., Miller, J. B., Baker, I. T., Tans, P. P., and White, J. W. C.: Novel applications of carbon isotopes in atmospheric $\mathrm{CO}_{2}$ : what can atmospheric measurements teach us about processes in the biosphere?, Biogeosciences, 8, 30933106, doi:10.5194/bg-8-3093-2011, 2011.

Bardgett, R. D., Freeman, C., and Ostle, N. J.: Microbial contributions to climate change through carbon cycle feedbacks, ISME J., 2, 805-814, doi:10.1038/ismej.2008.58, 2008.

Bird, J. A. and Torn, M. S.: Fine roots vs. Needles: A comparison of ${ }^{13} \mathrm{C}$ and ${ }^{15} \mathrm{~N}$ dynamics in a ponderosa pine forest soil, Biogeochemistry, 79, 361-382, 2006.

Borken, W. and Matzner, E.: Reappraisal of drying and wetting effects on $\mathrm{C}$ and $\mathrm{N}$ mineralization and fluxes in soils, Glob. Change Biol., 15, 808-824, doi:10.1111/j.13652486.2008.01681.x, 2009.

Bowling, D. R. and Massman, W. J.: Persistent wind-induced enhancement of diffusive $\mathrm{CO}_{2}$ transport in a mountain forest snowpack, J. Geophys. Res., 116, 15 pp., doi:10.1029/2011JG001722, 2011.

Bowling, D. R., Pataki, D. E., and Randerson, J. T.: Carbon isotopes in terrestrial ecosystem pools and $\mathrm{CO}_{2}$ fluxes, New Phytol., 178, 24-40, doi:10.1111/j.1469-8137.2007.02342.x, 2008.

Bowling, D. R., Massman, W. J., Schaeffer, S. M., Burns, S. P., Monson, R. K., and Williams, M. W.: Biological and physical influences on the carbon isotope content of $\mathrm{CO}_{2}$ in a subalpine forest snowpack, Niwot Ridge, Colorado, Biogeochemistry, 95, 37-59, doi:10.1007/s10533-008-9233-4, 2009.

Bowling, D. R., Grote, E. E., and Belnap, J.: Rain pulse response of soil $\mathrm{CO}_{2}$ exchange by biological soil crusts and grasslands of the semiarid Colorado Plateau, United States, J. Geophys. Res.Biogeo., 116, G03028, doi:10.1029/2011JG001643, 2011.

Bowling, D. R., Ballantyne, A. P., Miller, J. B., Burns, S. P., Conway, T. J., Menzer, O., Stephens, B. B., and Vaughn, B. H.: Ecological processes dominate the ${ }^{13} \mathrm{C}$ land disequilibrium in a Rocky Mountain subalpine forest, Global Biogeochem. Cy., 28, 352-370, doi:10.1002/2013GB004686, 2014.

Brüggemann, N., Gessler, A., Kayler, Z., Keel, S. G., Badeck, F., Barthel, M., Boeckx, P., Buchmann, N., Brugnoli, E., Esperschütz, J., Gavrichkova, O., Ghashghaie, J., Gomez-Casanovas, N., Keitel, C., Knohl, A., Kuptz, D., Palacio, S., Salmon, Y., Uchida, Y., and Bahn, M.: Carbon allocation and carbon isotope fluxes in the plant-soil-atmosphere continuum: a review, Biogeosciences, 8, 3457-3489, doi:10.5194/bg-8-3457-2011, 2011.

Carbone, M. S., Czimczik, C. I., McDuffee, K. E., and Trumbore, S. E.: Allocation and residence time of photosynthetic products in a boreal forest using a low-level ${ }^{14} \mathrm{C}$ pulse-chase labeling technique, Glob. Change Biol., 13, 466-477, 2007.

Cerling, T. E.: The stable isotopic composition of modern soil carbonate and its relationship to climate, Earth Planet. Sc. Lett., 71, 229-240, 1984.

Cerling, T. E., Solomon, D. K., Quade, J., and Bowman, J. R.: On the isotopic composition of carbon in soil carbon dioxide, Geochim. Cosmochim. Ac., 55, 3403-3405, 1991.

Clifton, A., Manes, C., Ruedi, J. D., Guala, M., and Lehning, M.: On shear-driven ventilation of snow, Bound.-Lay. Meteorol., 126, 249-261, 2008.

Cole, J. C. and Braddock, W. A.: Geologic Map of the Estes Park $30^{\prime} \times 60^{\prime}$ Quadrangle, North-Central Colorado, USGS Scientific Investigations Map 3039, US Geological Survey, available at: http://pubs.usgs.gov/sim/3039/ (last access: 27 August 2015), 2009. 
Conant, R. T., Ryan, M. G., Ågren, G. I., Birge, H. E., Davidson, E. A., Eliasson, P. E., Evans, S. E., Frey, S. D., Giardina, C. P., Hopkins, F. M., Hyvönen, R., Kirschbaum, M. U. F., Lavallee, J. M., Leifeld, J., Parton, W. J., Megan Steinweg, J., Wallenstein, M. D., Martin Wetterstedt, J. A., and Bradford, M. A.: Temperature and soil organic matter decomposition rates - synthesis of current knowledge and a way forward, Glob. Change Biol., 17, 3392-3404, doi:10.1111/j.1365-2486.2011.02496.x, 2011.

Davidson, E. A. and Janssens, I. A.: Temperature sensitivity of soil carbon decomposition and feedbacks to climate change, Nature, 440, 165-173, 2006.

Davidson, E. A., Belk, E., and Boone, R. D.: Soil water content and temperature as independent or confounded factors controlling soil respiration in a temperate mixed hardwood forest, Glob. Change Biol., 4, 217-227, 1998.

Davidson, G. R.: The stable isotopic composition and measurement of carbon in soil $\mathrm{CO}_{2}$, Geochim. Cosmochim. Ac., 59, 24852489, doi:10.1016/0016-7037(95)00143-3, 1995.

Dijkstra, F. A. and Cheng, W.: Interactions between soil and tree roots accelerate long-term soil carbon decomposition, Ecol. Lett., 10, 1046-1053, 2007.

Ekblad, A. and Högberg, P.: Natural abundance of ${ }^{13} \mathrm{C}$ in $\mathrm{CO}_{2}$ respired from forest soils reveals speed of link between tree photosynthesis and root respiration, Oecologia, 127, 305-308, 2001.

Epron, D., Bahn, M., Derrien, D., Lattanzi, F. A., Pumpanen, J., Gessler, A., Högberg, P., Maillard, P., Dannoura, M., Gérant, D., and Buchmann, N.: Pulse-labelling trees to study carbon allocation dynamics: a review of methods, current knowledge and future prospects, Tree Physiol., 32, 776-798, doi:10.1093/treephys/tps057, 2012.

Fang, C. and Moncrieff, J. B.: An open-top chamber for measuring soil respiration and the influence of pressure difference on $\mathrm{CO}_{2}$ efflux measurement, Funct. Ecol., 12, 319-325, 1998.

Fierer, N., Schimel, J. P., and Holden, P. A.: Influence of dryingrewetting frequency on soil bacterial community structure, Microb. Ecol., 45, 63-71, 2003.

Flechard, C. R., Neftel, A., Jocher, M., Ammann, C., Leifeld, J., and Fuhrer, J.: Temporal changes in soil pore space $\mathrm{CO}_{2}$ concentration and storage under permanent grassland, Agr. Forest Meteorol., 142, 66-84, 2007.

Formánek, P. and Ambus, P.: Assessing the use of $\delta^{13} \mathrm{C}$ natural abundance in separation of root and microbial respiration in a Danish beech (Fagus sylvatica L.) forest, Rapid Commun. Mass Sp., 18, 897-902, doi:10.1002/rcm.1424, 2004.

Friedlingstein, P., Meinshausen, M., Arora, V. K., Jones, C. D., Anav, A., Liddicoat, S. K., and Knutti, R.: Uncertainties in CMIP5 Climate Projections due to Carbon Cycle Feedbacks, J. Climate, 27, 511-526, doi:10.1175/JCLI-D-12-00579.1, 2014.

Fujiyoshi, R., Haraki, Y., Sumiyoshi, T., Amano, H., Kobal, I., and Vaupotic, J.: Tracing the sources of gaseous components $\left({ }^{222} \mathrm{Rn}\right.$, $\mathrm{CO}_{2}$ and its carbon isotopes) in soil air under a cool-deciduous stand in Sapporo, Japan, Environ. Geochem. Hlth., 32, 73-82, 2010 .

Gamnitzer, U., Moyes, A. B., Bowling, D. R., and Schnyder, H.: Measuring and modelling the isotopic composition of soil respiration: insights from a grassland tracer experiment, Biogeosciences, 8, 1333-1350, doi:10.5194/bg-8-1333-2011, 2011.

Ganot, Y., Dragila, M. I., and Weisbrod, N.: Impact of thermal convection on $\mathrm{CO}_{2}$ flux across the earth-atmosphere boundary in high-permeability soils, Agr. Forest Meteorol., 184, 12-24, doi:10.1016/j.agrformet.2013.09.001, 2014.

Ghashghaie, J. and Badeck, F. W.: Opposite carbon isotope discrimination during dark respiration in leaves versus roots - a review, New Phytol., 201, 751-769, doi:10.1111/nph.12563, 2014.

Goffin, S., Aubinet, M., Maier, M., Plain, C., Schack-Kirchner, H., and Longdoz, B.: Characterization of the soil $\mathrm{CO}_{2}$ production and its carbon isotope composition in forest soil layers using the flux-gradient approach, Agr. Forest Meteorol., 188, 45-57, doi:10.1016/j.agrformet.2013.11.005, 2014.

Heimann, M. and Reichstein, M.: Terrestrial ecosystem carbon dynamics and climate feedbacks, Nature, 451, 289-292, doi:10.1038/nature06591, 2008.

Högberg, P., Nordgren, A., Buchmann, N., Taylor, A. F. S., Ekblad, A., Högberg, M. N., Nyberg, G., Ottosson-Lofvenius, M., and Read, D. J.: Large-scale forest girdling shows that current photosynthesis drives soil respiration, Nature, 411, 789-792, 2001.

Högberg, P., Hogberg, M. N., Gottlicher, S. G., Betson, N. R., Keel, S. G., Metcalfe, D. B., Campbell, C., Schindlbacher, A., Hurry, V., Lundmark, T., Linder, S., and Nasholm, T.: High temporal resolution tracing of photosynthate carbon from the tree canopy to forest soil microorganisms, New Phytol., 177, 220-228, 2008.

Hopkins, F., Gonzalez-Meler, M. A., Flower, C. E., Lynch, D. J., Czimczik, C., Tang, J., and Subke, J.-A.: Ecosystem-level controls on root-rhizosphere respiration, New Phytol., 199, 339-351, doi:10.1111/nph.12271, 2013.

Irvine, J., Law, B. E., and Kurpius, M. R.: Coupling of canopy gas exchange with root and rhizosphere respiration in a semi-arid forest, Biogeochemistry, 73, 271-282, 2005.

Jarvis, P., Rey, A., Petsikos, C., Wingate, L., Rayment, M., Pereira, J., Banza, J., David, J., Miglietta, F., Borghetti, M., Manca, G., and Valentini, R.: Drying and wetting of Mediterranean soils stimulates decomposition and carbon dioxide emission: The "Birch effect," Tree Physiol., 27, 929-940, 2007.

Jassal, R., Black, A., Novak, M., Morgenstern, K., Nesic, Z., and Gaumont-Guay, D.: Relationship between soil $\mathrm{CO}_{2}$ concentrations and forest-floor $\mathrm{CO}_{2}$ effluxes, Agr. Forest Meteorol., 130, 176-192, doi:10.1016/j.agrformet.2005.03.005, 2005.

Keeling, C. D.: The concentration and isotopic abundances of atmospheric carbon dioxide in rural areas, Geochim. Cosmochim. Ac., 13, 322-334, 1958.

Kodama, N., Barnard, R., Salmon, Y., Weston, C., Ferrio, J., Holst, J., Werner, R., Saurer, M., Rennenberg, H., Buchmann, N., and Gessler, A.: Temporal dynamics of the carbon isotope composition in a Pinus sylvestris stand: from newly assimilated organic carbon to respired carbon dioxide, Oecologia, 156, 737750, 2008.

Kuzyakov, Y: Sources of $\mathrm{CO}_{2}$ efflux from soil and review of partitioning methods, Soil Biol. Biochem., 38, 425-448, doi:10.1016/j.soilbio.2005.08.020, 2006.

Kuzyakov, Y. and Gavrichkova, O.: REVIEW: Time lag between photosynthesis and carbon dioxide efflux from soil: a review of mechanisms and controls, Glob. Change Biol., 16, 3386-3406, doi:10.1111/j.1365-2486.2010.02179.x, 2010.

Lai, C.-T., Ehleringer, J. R., Schauer, A. J., Tans, P. P., Hollinger, D. Y., Paw U, K. T., Munger, J. W., and Wofsy, S. C.: Canopy-scale $\delta^{13} \mathrm{C}$ of photosynthetic and respiratory $\mathrm{CO}_{2}$ fluxes: observations in forest biomes across the United States, Glob. Change Biol., 11, 633-643, 2005. 
Le Quéré, C., Andres, R. J., Boden, T., Conway, T., Houghton, R. A., House, J. I., Marland, G., Peters, G. P., van der Werf, G. R., Ahlström, A., Andrew, R. M., Bopp, L., Canadell, J. G., Ciais, P., Doney, S. C., Enright, C., Friedlingstein, P., Huntingford, C., Jain, A. K., Jourdain, C., Kato, E., Keeling, R. F., Klein Goldewijk, K., Levis, S., Levy, P., Lomas, M., Poulter, B., Raupach, M. R., Schwinger, J., Sitch, S., Stocker, B. D., Viovy, N., Zaehle, S., and Zeng, N.: The global carbon budget 1959-2011, Earth Syst. Sci. Data, 5, 165-185, doi:10.5194/essd-5-165-2013, 2013.

Lewis Jr., W. M., and Grant, M. C.: Changes in the Output of Ions from a Watershed as a Result of the Acidification of Precipitation, Ecology, 60, 1093-1097, doi:10.2307/1936955, 1979.

Lloyd, J. and Taylor, J. A.: On the temperature dependence of soil respiration, Funct. Ecol., 8, 315-323, 1994.

Maier, M., Schack-Kirchner, H., Hildebrand, E. E., and Holst, J.: Pore-space $\mathrm{CO}_{2}$ dynamics in a deep, well-aerated soil, Eur. J. Soil Sci., 61, 877-887, 2010.

Marron, N., Plain, C., Longdoz, B., and Epron, D.: Seasonal and daily time course of the ${ }^{13} \mathrm{C}$ composition in soil $\mathrm{CO}_{2}$ efflux recorded with a tunable diode laser spectrophotometer (TDLS), Plant Soil, 318, 137-151, 2009.

Miller, J. B. and Tans, P. P.: Calculating isotopic fractionation from atmospheric measurements at various scales, Tellus, 55, 207214, 2003

Monson, R. K., Turnipseed, A. A., Sparks, J. P., Harley, P. C., ScottDenton, L. E., Sparks, K., and Huxman, T. E.: Carbon sequestration in a high-elevation, subalpine forest, Glob. Change Biol., 8, 459-478, 2002

Moyes, A. B. and Bowling, D. R.: Interannual variation in seasonal drivers of soil respiration in a semi-arid Rocky Mountain meadow, Biogeochemistry, 113, 683-697, doi:10.1007/s10533012-9797-x, 2013.

Moyes, A. B., Gaines, S. J., Siegwolf, R. T. W., and Bowling, D. R.: Diffusive fractionation complicates isotopic partitioning of autotrophic and heterotrophic sources of soil respiration, Plant Cell Environ., 33, 1804-1819, doi:10.1111/j.13653040.2010.02185.x, 2010.

Nickerson, N., Egan, J., and Risk, D.: Subsurface approaches for measuring soil $\mathrm{CO}_{2}$ isotopologue flux: Theory and application, J. Geophys. Res.-Biogeo., 119, 614-629, doi:10.1002/2013JG002508, 2014.

Parent, F., Plain, C., Epron, D., Maier, M., and Longdoz, B.: A new method for continuously measuring the $\delta 13 \mathrm{C}$ of soil $\mathrm{CO}_{2}$ concentrations at different depths by laser spectrometry, Eur. J. Soil Sci., 64, 516-525, doi:10.1111/ejss.12047, 2013.

Paterson, E., Midwood, A. J., and Millard, P.: Through the eye of the needle: a review of isotope approaches to quantify microbial processes mediating soil carbon balance, New Phytol., 184, 1933, doi:10.1111/j.1469-8137.2009.03001.x, 2009.

Phillips, C. L., Nickerson, N., Risk, D., Kayler, Z. E., Andersen, C., Mix, A., and Bond, B. J.: Soil moisture effects on the carbon isotope composition of soil respiration, Rapid Commun. Mass Sp., 24, 1271-1280, 2010.

Phillips, C. L., Nickerson, N., Risk, D., and Bond, B. J.: Interpreting diel hysteresis between soil respiration and temperature, Glob. Change Biol., 17, 515-527, 2011.

Placella, S. A., Brodie, E. L., and Firestone, M. K.: Rainfall-induced carbon dioxide pulses result from sequential resuscitation of phylogenetically clustered microbial groups, P. Natl. Acad. Sci. USA, 109, 10931-10936, 2012.

Powers, H. H., Hunt, J. E., Hanson, D. T., and McDowell, N. G.: A dynamic soil chamber system coupled with a tunable diode laser for online measurements of $\delta 13 \mathrm{C}, \delta 18 \mathrm{O}$, and efflux rate of soil-respired $\mathrm{CO}_{2}$, Rapid Commun. Mass Sp., 24, 243-253, doi:10.1002/rcm.4380, 2010.

Querejeta, J. I., Egerton-Warburton, L. M., and Allen, M. F.: Direct nocturnal water transfer from oaks to their mycorrhizal symbionts during severe soil drying, Oecologia, 134, 55-64, 2003.

Raich, J. W. and Schlesinger, W. H.: The global carbon dioxide flux in soil respiration and its relationship to vegetation and climate, Tellus B, 44, 81-99, doi:10.3402/tellusb.v44i2.15428, 1992.

Rayment, M. B. and Jarvis, P. G.: An improved open chamber system for measuring soil $\mathrm{CO}_{2}$ effluxes in the field, J. Geophys. Res.-Atmos., 102, 28779-28784, 1997.

Riggs, A. C., Stannard, D. I., Maestas, F. B., Karlinger, M. R., and Striegl, R. G.: Soil $\mathrm{CO}_{2}$ flux in the Amargosa Desert, Nevada, during El Nino 1998 and La Nina 1999, US Geol. Surv. Sci. Investig. Rep. 2009-5061, available at: http://pubs.usgs.gov/sir/ 2009/5061/ (last access: 27 August 2015), 2009.

Risk, D., Nickerson, N., Phillips, C. L., Kellman, L. and Moroni, M.: Drought alters respired $\delta^{13} \mathrm{CO}_{2}$ from autotrophic, but not heterotrophic soil respiration, Soil Biol. Biochem., 50, 26-32, doi:10.1016/j.soilbio.2012.01.025, 2012.

Roland, M., Vicca, S., Bahn, M., Ladreiter-Knauss, T., Schmitt, M. and Janssens, I. A.: Importance of non-diffusive transport for soil $\mathrm{CO}_{2}$ efflux in a temperate mountain grassland, J. Geophys. Res.Biogeo., 502-512, doi:10.1002/2014JG002788, 2015.

Sánchez-Cañete, E. P., Kowalski, A. S., Serrano-Ortiz, P., PérezPriego, O., and Domingo, F.: Deep $\mathrm{CO}_{2}$ soil inhalation / exhalation induced by synoptic pressure changes and atmospheric tides in a carbonated semiarid steppe, Biogeosciences, 10, 6591-6600, doi:10.5194/bg-10-6591-2013, 2013.

Savage, K., Davidson, E. A., and Tang, J.: Diel patterns of autotrophic and heterotrophic respiration among phenological stages, Glob. Change Biol., 19, 1151-1159, 2013.

Schaeffer, S. M., Miller, J. B., Vaughn, B. H., White, J. W. C., and Bowling, D. R.: Long-term field performance of a tunable diode laser absorption spectrometer for analysis of carbon isotopes of $\mathrm{CO}_{2}$ in forest air, Atmos. Chem. Phys., 8, 5263-5277, doi:10.5194/acp-8-5263-2008, 2008.

Scott-Denton, L. E., Sparks, K. L., and Monson, R. K.: Spatial and temporal controls of soil respiration rate in a high-elevation, subalpine forest, Soil Biol. Biochem., 35, 525-534, 2003.

Seok, B., Helmig, D., Williams, M. W., Liptzin, D., Chowanski, K., and Hueber, J.: An automated system for continuous measurements of trace gas fluxes through snow: An evaluation of the gas diffusion method at a subalpine forest site, Niwot Ridge, Colorado, Biogeochemistry, 95, 95-113, 2009.

Sommerfeld, R. A., Musselman, R. C., Reuss, J. O., and Mosier, A. R.: Preliminary measurements of $\mathrm{CO}_{2}$ in melting snow, Geophys. Res. Lett., 18, 1225-1228, 1991.

Staebler, R. M. and Fitzjarrald, D. R.: Measuring Canopy Structure and the Kinematics of Subcanopy Flows in Two Forests, J. Appl. Meteorol., 44, 1161-1179, doi:10.1175/JAM2265.1, 2005.

Subke, J. A., Reichstein, M., and Tenhunen, J. D.: Explaining temporal variation in soil $\mathrm{CO}_{2}$ efflux in a mature spruce forest in Southern Germany, Soil Biol. Biochem., 35, 1467-1483, 2003. 
Tóta, J., Roy Fitzjarrald, D., and da Silva Dias, M. A. F.: Amazon Rainforest Exchange of Carbon and Subcanopy Air Flow: Manaus LBA Site - A Complex Terrain Condition, Sci. World J., 2012, 165067, doi:10.1100/2012/165067, 2012.

Unger, S., Máguas, C., Pereira, J. S., David, T. S., and Werner, C.: Interpreting post-drought rewetting effects on soil and ecosystem carbon dynamics in a Mediterranean oak savannah, Agr. Forest Meteorol., 154-155, 9-18, 2012.

Vickers, D. and Thomas, C. K.: Observations of the scaledependent turbulence and evaluation of the flux-gradient relationship for sensible heat for a closed Douglas-fir canopy in very weak wind conditions, Atmos. Chem. Phys., 14, 9665-9676, doi:10.5194/acp-14-9665-2014, 2014

Werner, C. and Gessler, A.: Diel variations in the carbon isotope composition of respired $\mathrm{CO}_{2}$ and associated carbon sources: a review of dynamics and mechanisms, Biogeosciences, 8, 24372459, doi:10.5194/bg-8-2437-2011, 2011.
Wingate, L., Ogee, J., Burlett, R., Bosc, A., Devaux, M., Grace, J., Loustau, D., and Gessler, A.: Photosynthetic carbon isotope discrimination and its relationship to the carbon isotope signals of stem, soil and ecosystem respiration, New Phytol., 188, 576589, 2010.

Xiong, Y., D'Atri, J. J., Fu, S., Xia, H., and Seastedt, T. R.: Rapid soil organic matter loss from forest dieback in a subalpine coniferous ecosystem, Soil Biol. Biochem., 43, 2450-2456, 2011.

Xu, L. K., Furtaw, M. D., Madsen, R. A., Garcia, R. L., Anderson, D. J., and McDermitt, D. K.: On maintaining pressure equilibrium between a soil $\mathrm{CO}_{2}$ flux chamber and the ambient air, J. Geophys. Res.-Atmos., 111, D08S10, doi:10.1029/2005JD006435, 2006. 